\title{
DOE/ER/13035- T3
}

FINAL REPORT

\section{Reactions and Moderators}

for an Accelerator-Based

Epithermal Neutron Capture Therapy

Source for Cancer Treatment

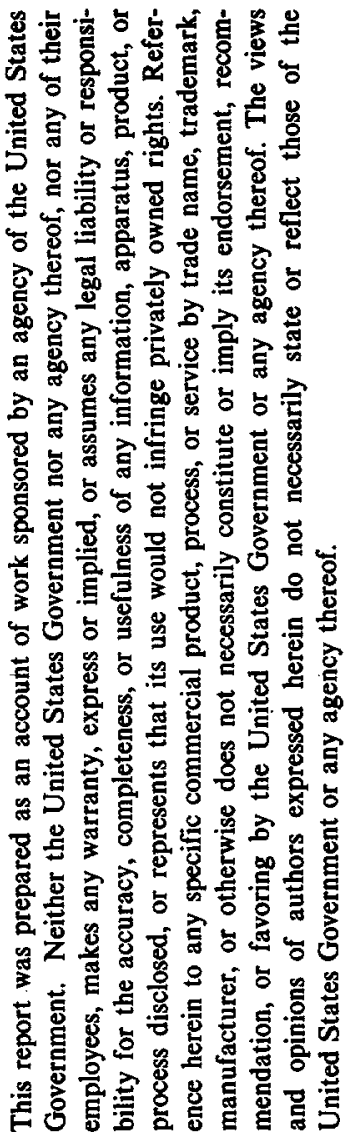

\author{
Jay F. Kunze \\ Robert M. Brugger
}

University of Missouri

Nuclear Engineering Program

E-2433 Engineering Bldg.

Columbia, MO 65211

Phone: $314-882-3550$

FAX: $314-884-4801$

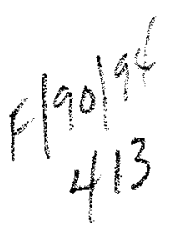

March 1995

Performed Under Contract \# DE-FG02-90ER13035

from the U.S. Department of Energy

October 1990 to Sept. 1994 


\section{DISCLAIMER}

Portions of this document may be illegible in electronic image products. Images are produced from the best available original document. 


\section{INTRODUCTION and BACKGROUND}

The use of boron neutron capture therapy (BNCT) has been considered for nearly 30 years, and been practiced in Japan since the late 1970's. Early experiments in the USA were generally nonpromising. However, new boron-containing ligand compounds were developed, which would seek out brain tumors. Concentration levels of the order of 30 micrograms of boron per gram of tissue become possible, and interest in the BNCT technique was revived in the USA beginning about 1985, with research reactors as the obvious source of the neutrons for the treatment. However, the limited number of research reactors in the USA (and the world) would mean that this treatment modality would be quite limited. With approximately 11,000 new cases of nominally inoperable brain cancer developing each year in the USA, it appeared that there would be a more general need for facilities to do BNCT. Consequently, the idea of having an accelerator source to produce the neutrons was developed. Accelerators do not have to be licensed by the NRC, nor would any activation products so produced be subject to NRC license. Furthermore, accelerators are much less expensive to build and install than are reactors (even the simple, ultra-safe systems such as the TRIGA).

This work originally had two goals:

1) Examine as many as possible reactions of charged particles on various targets of an accelerator, and determine those that would give high neutron yields of a convenient energy.

2) Determine, through calculations (using Monte Carlo stochastic computer codes), the best design for a moderator/reflector assembly which would give high thermal flux at a nominal $5 \mathrm{~cm}$ depth in the head of a patient, with minimal radiation dose from gamma rays and fast neutrons.

After completing these two studies, well within budget and time schedule, it was decided that the calculations were of questionable reliability without an experimental comparison, i.e. a benchmark. Hence it was proposed to add a third task, within the same initial budget, but with a longer time schedule, as follows:

3) Perform a benchmark experiment using a positive ion accelerator. The Li-7(p,n) reaction was chosen for the benchmark, since it was readily available for most accelerators, and was one of the two highest yielding reactions from Task \#1. Since the University of Missouri has no accelerator, possible accelerators at other universities were investigated, as to availability and cost. A unit having capability in the $2.5 \mathrm{MeV}$ range was desired.

It was decided to perform the experiments at the Physics Department of the Idaho State University in Pocatello, Idaho, where a VandeGraff generator was available, at a nominal $2 \mathrm{MeV}$ rating, but with operational capability up to about $2.3 \mathrm{MeV}$. Furthermore, a new radiofrequency quadrupole (RFQ) positive ion generator was being installed. by the Idaho National Engineering Laboratory, at the Idaho State University Physics Department. It was indicated that the fixed energy $(2.0 \mathrm{MeV})$ generator possibly could be available for use on the project. 


\subsection{BRIEF CHRONOLOGICAL SUMMARY}

Initiation: The project commenced in November 1990, with simultaneous studies on tasks \#1 and $\# 2$.

Task \#1 - Study of Possible Reactions: The reactions studied (Task \#1) were all obtained from literature, much of it dating back to the 1940 's. . The $\mathrm{Li}-7(\mathrm{p}, \mathrm{n})$ and $\mathrm{H}-3(\mathrm{p}, \mathrm{n})$ reactions were the highest yielding reactions, with yields of 1.5 and 2.2 neutrons per 10,000 protons, respectively, for proton energies that would not give neutrons energies above $800 \mathrm{keV}$. Tables 1 through 4 give the results of the various reactions studied from the literature. For the most promising of these, the differential cross section data was used, along with energy loss of the charged particles in the target, to compute overall neutron production from a thick target. The last column in these tables gives the results of these calculations.. In the case of the Li-7 $(p, n)$ reaction, a detailed study of the calculated differential cross section yields for the neutrons was done and compared with available experimental data in the literature. Figure 1 shows the results of these calculations compared with experiments, for the proton energy of $1.95 \mathrm{MeV}$, just slightly above the 1.88 $\mathrm{MeV}$ threshold energy. A summary of these results was presented in Reference \#1. (Appendix. A).

This task was essentially completed in March 1992

Task \#2 - Moderator-Reflector Design: For the moderator-reflector design, only the Li-7(n,p) and $\mathrm{H}-3(\mathrm{p}, \mathrm{n})$ reactions were studied. This effort had a criteria to limit the energy of the protons to levels that would not produce excessive inelastic scattering, and hence significant gamma ray production. For the $\mathrm{Li}-7(\mathrm{p}, \mathrm{n})$ reaction, the proton energy was limited to $2.5 \mathrm{MeV}$, giving a corresponding maximum neutron energy of $0.787 \mathrm{MeV}$, as summarized below:

\section{$\mathrm{Li}-7(\mathbf{p}, \mathbf{n}) \mathrm{Be}-7 *$ Reaction}

\begin{tabular}{|l|l|}
\hline Q-value of the reaction & $-1.645 \mathrm{MeV}$ \\
\hline Threshold Energy, E-threshold & $1.881 \mathrm{MeV}$ \\
\hline Neutron Energy at E-threshold & $0.029 \mathrm{MeV}$ \\
\hline Incident Proton Energy for Study & $2.50 \mathrm{MeV}$ \\
\hline Maximum Neutron Energy & $0.787 \mathrm{MeV}$ \\
\hline Total Neutron Yield & 1.48 neutrons per 10.000 protons \\
\hline
\end{tabular}

The $\mathrm{H}-3(\mathrm{p}, \mathrm{n}) \mathrm{He}-3$ reaction represents a difficult one to design the target. Nevertheless the computer study was made, assuming a "thick" H-3 target. The maximum neutron energy was limited to $1 \mathrm{MeV}$, thus resulting in the need for only $1.77 \mathrm{MeV}$ proton energy. The results were as follows: 
H-3(p,n)He-3 Reaction

\begin{tabular}{|l|l|}
\hline Q-value of the reaction & $-0.764 \mathrm{MeV}$ \\
\hline Threshold Energy, E-threshold & $1.019 \mathrm{MeV}$ \\
\hline Neutron Energy at E-threshold & $0.064 \mathrm{MeV}$ \\
\hline Incident Proton Energy for Study & $1.77 \mathrm{MeV}$ \\
\hline Maximum Neutron Energy & $1.0 \mathrm{MeV}$ \\
\hline Total Neutron Yield & 2.54 neutrons per 10,000 protons \\
\hline
\end{tabular}

The moderator design concluded that, in the case of the $\mathrm{Li}-7$ reaction, beryllium made the best moderator (slightly better than heavy water), and $\mathrm{MgO}$ was a slightly better reflector than the convention use of aluminum oxide.

The results of this study are given in more detail in Reference 2 (Appendix B). This task was essentially complete by August 1992, and a publication was submitted to the 4th International Conference on Neutron Capture Therapy held in Columbus, Ohio in September 1992 (Ref. 2).

\section{Task \#3 - Benchmark Experiment}

The first attempt at a benchmark experiment was made in the Spring of 1992, using the VandeGraff generator at the Physics Dept. of Idaho State University. The machine was operated at 2.2 to $2.25 \mathrm{MeV}$, because is was desired to obtain results as close to the design proton energy $(2.5 \mathrm{MeV})$ of Task 2 as possible, and also to be on the flat part of the curve. The experiments, which were run for a week, but were largely a failure because of voltage breakdown in the machine, which made it impossible to hold a steady beam for more than a few seconds.

However, lessons were learned on the sensitivity of the integration flux measurement foils (gold and indium) to the neutron levels in the experiment. Beam current averaged no more than 4 microamps.

In October 1993 the measurements were again attempted, this time on the $2.0 \mathrm{MeV}$ fixed energy RFQ machine. However, after setting up the experiment, the machine failed to work because of a burned out filament and no replacements available from the manufacturer.

In May 1994, the experiment was again attempted with the RFQ machine, this time successfully with a number of variations in the configurations. Even some multiplying configurations were measured. Machine output average about 70 microamps. Neutron production was about 4 times that from the VandeGraff experiments in April 1992, at the higher energy. Comparisons were made with each configuration and the results of the MCNP Monte Carlo computer code calculations of the same configuration. The conclusion was that the computer model 
substantially over-predicted the flux at the $3.8 \mathrm{~cm}$ depth in the phantom, typical of a tumor depth. The predictions at the target and the entrance to the phantom agreed well with experiment. Gamma measurements were inconclusive, however, because of inadequate reliability of the TLD measurements.

The allowed intensity of the proton beam on the target, without damaging the target, is the main limitation to obtaining the necessary neutron yield. This limitation has been readily recognized by a number of other investigators as well. However, upon completing these experiments at the lower energy ( $2.0 \mathrm{MeV}$ protons), it became obvious that the lower maximum neutron energy $(0.228 \mathrm{MeV})$ would make it feasible to use much less moderator around the target, and hence the patient could be placed much closer to the target. Studies on this option have been initiated using the computer and the MCNP code. These are being carried out at the University of Missouri, and some additional measurements using internal funding are planned for the future, in cooperation with Idaho State University Department of Physics.

\subsection{Personnel Involved, Degrees Awarded from Work, and Publications}

\subsection{Personnel}

Dr. Robert Brugger was the original principal investigator, assisted by Dr. Jay Kunze. Dr. Brugger retired from the University of Missouri in August 1991, and continued his work related to BNCT, but at Brookhaven National Laboratory. Dr. Kunze continued supervising the work, and defined Task \#3, carrying it to its conclusion, as stated above. However, Dr. Brugger continued to keep informed of the progress of the work and provided advice.

Students who received degrees from this work were:

1) Lo, Yi-Wang (Frank), PhD (scheduled for August 1995), "Comparison of Monte Carlo

Techniques with Integral Neutron Spectral Measurements on a Accelerator Neutron Source for a BNCT"

2) Luo, Jianbin, M.S., Nuclear Engineering, 1995, "Benchmark Experiments for BNCT System"

3) Kumuduni Kulasekere, MS, Nuclear Engineering, 1994. "A Calculation Using 'QAD' to

Evaluate Gamma Dose Rates Produced by Accelerator-based Neutron Sources for BNCT"

4) Terry H. Wu, PhD, Nuclear Engineering, 1992, "A Low Energy Accelerator-Based Neutron Source for Neutron-Capture Therapy"

5) D. Jay Moreno Jalandoni, MS, Medical Physics emphasis in Nuclear Engineering, 1992, "An Experiment to Evaluate Calculations for the Design of an Accelerator for Boron Neutron Capture (Cancer) Therapy"

In addition, one student (Rajat Kudchadker) is well along the way toward completing his dissertation, having participated actively in the benchmark experiments of Task \#3. However, his work is not being funded by the DOE grant (which has expired).

Dr. Frank Harmon, Chairman of Physics at Idaho State University, was most instrumental in making Task \#3 possible to accomplish, and participated directly in the benchmark experiments. 
It was through his efforts that the RFQ machine, owned by the Idaho National Engineering Laboratory, was made available for this work.

\subsection{Publications}

1) Brugger, RM., X. Luo, J.F. Kunze, "Targets for the Production of Neutrons from Low Energy Positive ion Accelerators", TRANS. Am. Nuclear Society, 65, p.146 June 1992

2) Wu, H-S, R.M. Brugger, and J.F.Kunze, "Low Energy Accelerator-based Neutron Source for Neutron Capture Therapy", Advances in Neutron Capture Therapy, edited by A.

Soloway et al, p.105, (Pergamon, 1993)

3) Kunze, J.F., R.Kudchadker, J.Luo,Y.Lo, F. Harmon, "Results of Benchmark Experiment of Accelerator/Moderator Configuration for BNCT - Using RFQ Accelerator", Proceedings of 1st International Conference on Accelerator Sources for Neutron Capture Therapy, Sept. 1994, p.243 to 253.

\subsection{EXPENDITURES}

Total expenditures on the Project, over the 4-year period, were approximately $\$ 200,000$, of which $\$ 143,700$ was provided by the U.S. Dept. of Energy grant, and the remainder was "cost sharing" from the University of Missouri. 
Table $1(p, n)$ Reactions with $E_{n \max }=800 \mathrm{keV}$.

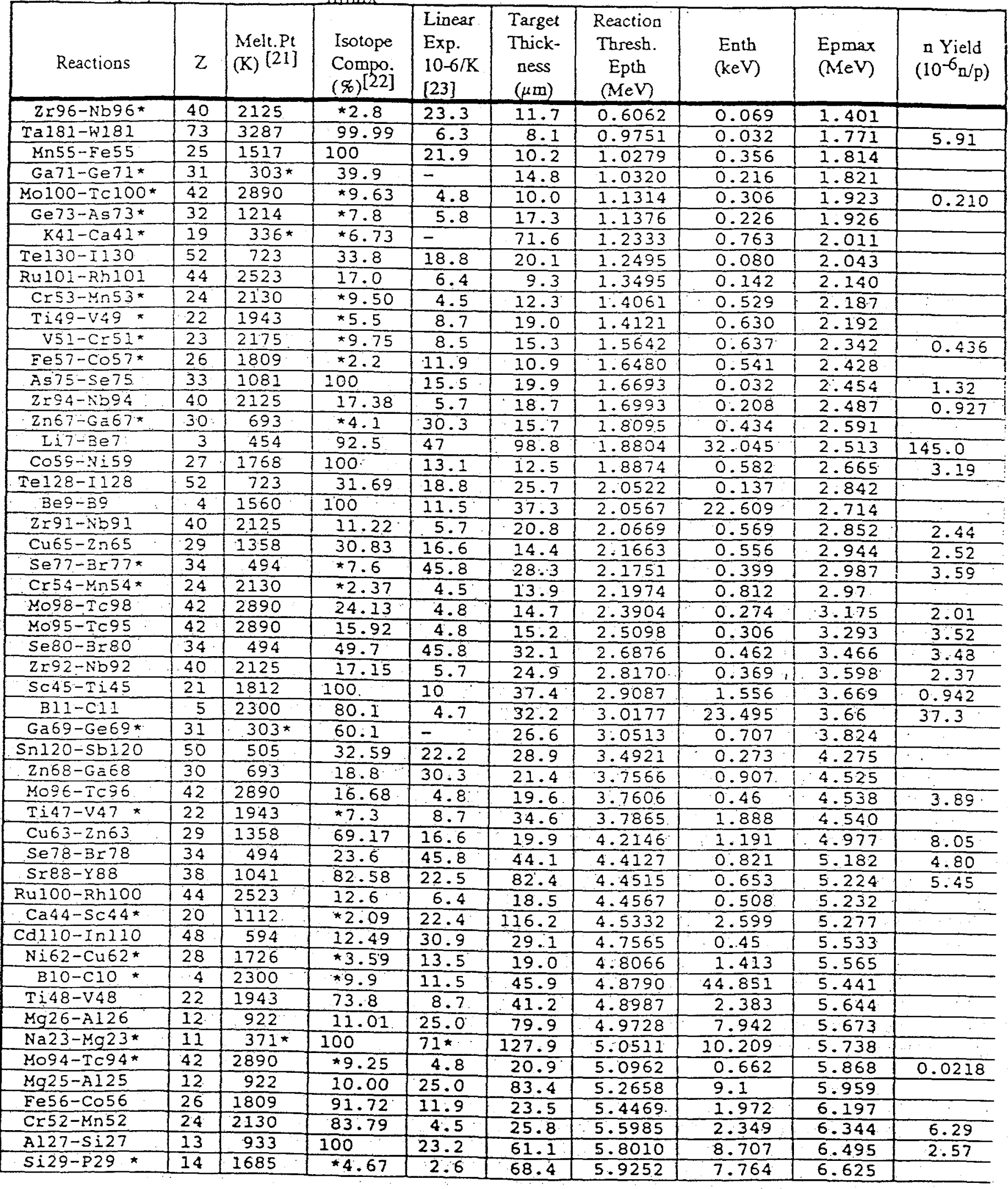




\begin{tabular}{|c|c|c|c|c|c|c|c|c|c|}
\hline Se76-Br76* & 34 & 494 & $\star 9.0$ & 45.8 & 48.1 & 5.9636 & 1.191 & 6.724 & 7.57 \\
\hline Zn66-Ba66 & 30 & 693 & 27.9 & 30.3 & 29.6 & 6.0485 & 1.598 & 6.803 & \\
\hline $5 r 86-Y 86$ * & 38 & 1041 & $\star 9.86$ & 22.5 & 90.4 & 6.1264 & 0.961 & 6.891 & 6.97 \\
\hline P31-s31* & 15 & $317 *$ & 100 & - & 98.3 & 6.6246 & 7.446 & 7.125 & \\
\hline Ni60-Cu60 & 28 & 1726 & 26.10 & 13.5 & 24.9 & 7.0256 & 2.264 & 7.77 & \\
\hline $\mathrm{K} 39-\mathrm{Ca} 39{ }^{*}$ & 19 & $336 *$ & 93.26 & - & 234.0 & 7.4938 & 5.632 & 8.206 & \\
\hline $2 n 64-G a 64$ & 30 & 693 & 48.6 & 30.3 & 36.1 & 7.9763 & 2.287 & 8.72 & \\
\hline $\mathrm{Ti46-V46*}$ & 22 & 1943 & $\star 8.0$ & 8.7 & 58.7 & 9.0087 & 4.387 & 8.73 & \\
\hline Fe54-Co54* & 26 & 1809 & $\star 5.8$ & 11.9 & 34.3 & 9.2006 & 3.728 & 9.927 & \\
\hline Ni58-Cu 58 & 28 & 1726 & 68.27 & 13.5 & 31.2 & 9.5123 & 3.36 & 10.244 & \\
\hline $\operatorname{si32-Cl32}$ & 16 & 1685 & 95.02 & 2.6 & 131.6 & 13.9606 & 16.3 & 14.604 & \\
\hline $\mathrm{Mg} 24-\mathrm{Al} 24$ & 12 & 922 & 78.99 & 25.0 & 164.3 & 15.2815 & 31.292 & 15.866 & \\
\hline Ca $40-\operatorname{sc} 40$ & 20 & 1112 & 96.94 & 22.4 & 258.0 & 15.4880 & 9.537 & 16.154 & \\
\hline si28-p28 & 14 & 1685 & 92.23 & 2.6 & 125.9 & 15.6642 & 29.47 & 16.275 & \\
\hline $\mathrm{C} 12-\mathrm{N} 12$ & 6 & 4100 & 98.9 & 1.1 & 95.5 & 19.6484 & 123.092 & 20.000 & \\
\hline
\end{tabular}

* -- Low melting point, \& low percentage in composition of the natural element.

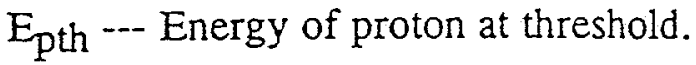

$E_{\text {nth. }}$-- Kinetic energy of the produced neutrons at threshold in the forward direction in the laboratory system.

$\mathrm{E}_{\mathrm{pmax}}$--- Kinetic energy of proton necessary to produce $800 \mathrm{keV}$ neutrons in the forward direction in the laboratory system. 
Table 2a. Target design with $E_{n \max }=800 \mathrm{keV}$.

\begin{tabular}{|c|c|c|c|c|c|c|}
\hline Elements & $\begin{array}{c}\text { Melt. Pt. } \\
(\mathrm{K})\end{array}$ & $\begin{array}{c}\text { Composition } \\
(\%)\end{array}$ & $\begin{array}{l}\text { Thresh. } \\
(\mathrm{MeV})\end{array}$ & $\begin{array}{l}\text { Neutron } \\
\text { Energy at } \\
\text { Epth(keV) }\end{array}$ & $\begin{array}{c}\text { Max.Proton } \\
\text { Energy } \\
\text { (MeV) }\end{array}$ & $\begin{array}{l}\text { Neutron } \\
\text { Yield } \\
\left(10^{-6} \mathrm{n} / \mathrm{p}\right)\end{array}$ \\
\hline $\begin{array}{l}\text { Ta-181 or } \\
\text { Mn- } 55\end{array}$ & $\begin{array}{l}3287 \\
1517 \\
\end{array}$ & $\begin{array}{l}99.988 \\
100\end{array}$ & $\begin{array}{l}0.98 \\
1.03 \\
\end{array}$ & $\begin{array}{l}0.0319 \\
0.356\end{array}$ & $\begin{array}{l}1.77 \\
1.81 \\
\end{array}$ & $\begin{array}{l}5.91 \\
--\quad \\
\end{array}$ \\
\hline $\begin{array}{l}\mathrm{Zn}-67 \text { or } \\
\mathrm{Li}-7\end{array}$ & $\begin{array}{l}693 \\
453.7 \\
\end{array}$ & $\begin{array}{l}4.11 \\
92.5 \\
\end{array}$ & $\begin{array}{l}1.81 \\
1.88 \\
\end{array}$ & $\begin{array}{c}0.434 \\
32.05\end{array}$ & $\begin{array}{l}2.59 \\
2.51\end{array}$ & 148.00 \\
\hline $\mathrm{Se}-80$ & 494 & 49.7 & 2.69 & 0.462 & 3.47 & 3.48 \\
\hline $\mathrm{Sn}-120$ & 505 & 32.59 & 3.49 & 0.273 & 4.28 & $\ldots$ \\
\hline $\mathrm{Cu}-63$ & 1358 & 69.17 & 4.21 & 1.191 & 4.98 & 8.05 \\
\hline $\mathrm{Mg}-26$ & 922 & 11.01 & 4.97 & 7.942 & 5.67 & $\cdots$ \\
\hline Cr-52 & 2130 & 83.79 & 5.60 & 2.349 & 6.34 & 6.29 \\
\hline
\end{tabular}

Total Yield: $\quad \sim 1.84 \times 10^{-4} \mathrm{n} / \mathrm{p}$.

Table 2b. Target design with $\mathrm{E}_{\mathrm{n}_{\max }}=800 \mathrm{keV}$.

\begin{tabular}{|c|c|c|c|l|l|l|}
\hline Element & $\begin{array}{c}\text { Melt.pt } \\
(\mathrm{K})\end{array}$ & $\begin{array}{c}\text { Compositio } \\
\mathrm{n} \\
(\%)\end{array}$ & $\begin{array}{c}\text { Thresh. } \\
\text { Epth } \\
(\mathrm{MeV})\end{array}$ & $\begin{array}{c}\text { Neutron } \\
\text { Energy at } \\
\text { Epth(keV) }\end{array}$ & $\begin{array}{c}\text { Max.Protn } \\
\text { Energy } \\
(\mathrm{MeV})\end{array}$ & $\begin{array}{c}\text { Neutron } \\
\text { Yield } \\
\left(10^{-6} \text { n/p) }\right.\end{array}$ \\
\hline $\mathrm{Mn}-55$ & 1517 & 100 & 1.0279 & 0.356 & 1.814 & \\
\hline $\mathrm{Te}-128$ & 723 & 31.69 & 2.0522 & 0.137 & 2.842 & \\
\hline $\mathrm{Sn}-120$ & 505 & 32.59 & 3.4921 & 0.273 & 4.275 & \\
\hline $\mathrm{Cu}-63$ or & 1358 & 69.17 & 4.2146 & 1.191 & 4.977 & 8.05 \\
$\mathrm{Sr}-88$ & 1041 & 82.58 & 4.4515 & 0.653 & 5.224 & 5.45 \\
\hline $\mathrm{Mg}-25$ & 922 & 10.00 & 5.2658 & 9.1 & 5.959 & \\
\hline
\end{tabular}

Total yield: $\sim 4.025 \times 10^{-5} \mathrm{n} / \mathrm{p}$. 
Table 2c. Target design with $E_{n \max }=800 \mathrm{keV}$.

\begin{tabular}{|c|c|c|c|c|c|c|}
\hline Elements & $\begin{array}{c}\text { Melt. Pt. } \\
(\mathrm{K})\end{array}$ & $\begin{array}{c}\text { Composition } \\
(\%)\end{array}$ & $\begin{array}{l}\text { Thresh. } \\
\text { (MeV) }\end{array}$ & $\begin{array}{c}\text { Neutron } \\
\text { Energy at } \\
\text { Epth (keV) }\end{array}$ & $\begin{array}{l}\text { Max.Proton } \\
\text { Energy } \\
(\mathrm{MeV})\end{array}$ & $\begin{array}{c}\text { Neutron } \\
\text { Yield } \\
\left(10^{-6}{ }_{n} / \mathrm{p}\right) \\
\end{array}$ \\
\hline $\mathrm{Zr}-96$ & 693 & 2.8 & .61 & 0.0689 & 1.4 & $-\quad x$ \\
\hline Cr-53 & 2130 & 9.501 & 1.41 & 0.529 & 2.19 & $\ldots$ \\
\hline Cr -54 & 2130 & 2.365 & 2.20 & 0.812 & 2.97 & $-\cdots$ \\
\hline B-11 & 2300 & 80.1 & 3.02 & 23.495 & 3.66 & - \\
\hline $\mathrm{Zn}-68$ & 693 & 18.8 & 3.76 & 0.907 & 4.525 & - \\
\hline $\mathrm{Ca}-44$ & 1112 & 2.086 & 4.53 & 2.599 & 5.277 & $\cdots$ \\
\hline $\mathrm{Mg}-25$ & 922 & 11.01 & 5.27 & 9.10 & 5.959 & $-\cdots$ \\
\hline
\end{tabular}

Table 2d. Target design with $E_{n_{\max }}=800 \mathrm{keV}$.

\begin{tabular}{|c|c|c|c|c|c|c|}
\hline Elements & $\begin{array}{l}\text { Melt. Pt. } \\
\text { (K) }\end{array}$ & $\begin{array}{c}\text { Composition } \\
(\%)\end{array}$ & $\begin{array}{l}\text { Thresh. } \\
(\mathrm{MeV})\end{array}$ & $\begin{array}{l}\text { Neutron } \\
\text { Energy at } \\
\text { Epth(keV) }\end{array}$ & $\begin{array}{c}\text { Max.Proton } \\
\text { Energy } \\
(\mathrm{MeV})\end{array}$ & $\begin{array}{l}\text { Neutron } \\
\text { Yield } \\
\left(10^{-} \sigma_{n / p}\right)\end{array}$ \\
\hline Mo-100 & 2890 & 9.63 & 1.13 & 0.306 & 1.92 & $0.210 \quad x$ \\
\hline $\begin{array}{l}\text { Co-59 or } \\
\text { Te-128 or } \\
\text { Cu }-65\end{array}$ & $\begin{array}{r}1768 \\
723 \\
1358\end{array}$ & $\begin{array}{l}100 \\
31.69 \\
30.83\end{array}$ & $\begin{array}{l}1.89 \\
2.05 \\
2.17\end{array}$ & $\begin{array}{l}0.582 \\
0.137 \\
22.61\end{array}$ & $\begin{array}{l}2.67 \\
2.84 \\
2.94\end{array}$ & $\begin{array}{l}3.19 \\
-2 . \\
2.52\end{array}$ \\
\hline $\begin{array}{l}\mathrm{Se}-80 \text { or } \\
\mathrm{Zr}-92 \text { or } \\
\mathrm{Sc}-45\end{array}$ & $\begin{array}{r}494 \\
2125 \\
1812 \\
\end{array}$ & $\begin{array}{c}49.7 \\
17.15 \\
100 \\
\end{array}$ & $\begin{array}{l}2.69 \\
2.82 \\
2.91\end{array}$ & $\begin{array}{l}0.462 \\
0.369 \\
1.556\end{array}$ & $\begin{array}{l}.47 \\
3.60 \\
3.67 \\
\end{array}$ & $\begin{array}{l}3.48 \\
2.37^{\prime} \\
0.942 \\
\end{array}$ \\
\hline $\begin{array}{l}\mathrm{Sn}-120 \text { or } \\
\mathrm{Zn}-68\end{array}$ & $\begin{array}{r}505 \\
693 \\
\end{array}$ & $\begin{array}{l}32.59 \\
18.8 \\
\end{array}$ & $\begin{array}{l}3.49 \\
3.75 \\
\end{array}$ & $\begin{array}{l}0.273 \\
0.907 \\
\end{array}$ & $\begin{array}{l}4.28 \\
4.53 \\
\end{array}$ & $-\ldots$ \\
\hline $\begin{array}{l}\mathrm{Cu}-63 \text { or } \\
\mathrm{Sr}-88 \text { or } \\
\mathrm{Ca}-44\end{array}$ & $\begin{array}{l}1358 \\
1041 \\
1112\end{array}$ & $\begin{array}{c}69.17 \\
82.58 \\
2.086\end{array}$ & $\begin{array}{l}4.21 \\
4.45 \\
4.53\end{array}$ & $\begin{array}{l}1.191 \\
0.653 \\
2.599\end{array}$ & $\begin{array}{l}4.98 \\
5.22 \\
5.28\end{array}$ & $\begin{array}{l}8.05 \\
5.45 \\
-\end{array}$ \\
\hline $\begin{array}{l}\mathrm{Mo}-94 \text { or } \\
\mathrm{Mg}-25 \text { or } \\
\mathrm{Fe}-56 \text { or } \\
\mathrm{Al}-27\end{array}$ & $\begin{array}{r}2890 \\
922 \\
1809 \\
933\end{array}$ & $\begin{array}{l}9.25 \\
10 \\
91.72 \\
100\end{array}$ & $\begin{array}{l}5.10 \\
5.27 \\
5.45 \\
5.80\end{array}$ & $\begin{array}{l}0.662 \\
9.10 \\
1.972 \\
8.707\end{array}$ & $\begin{array}{l}5.87 \\
5.96 \\
6.20 \\
6.50\end{array}$ & \begin{tabular}{l}
$0.0218 \times$ \\
$\cdots$ \\
\hdashline-5 \\
2.57
\end{tabular} \\
\hline
\end{tabular}

Total yield: $\sim 1.57 \times 10^{-5} \mathrm{n} / \mathrm{p}$. 
Table 3 Target design with $\mathrm{E}_{\max }=500 \mathrm{keV}$.

\begin{tabular}{|l|c|l|l|l|l|l|}
\hline Elements & $\begin{array}{c}\text { Melt. Pt. } \\
(\mathrm{K})\end{array}$ & $\begin{array}{c}\text { Isotope } \\
\text { Compositin } \\
(\%)\end{array}$ & $\begin{array}{c}\text { Thresh. } \\
(\mathrm{MeV})\end{array}$ & $\begin{array}{c}\text { Neutron } \\
\text { Energy at } \\
\text { Epth (keV) }\end{array}$ & $\begin{array}{c}\text { Max.Proton } \\
\text { Energy } \\
(\mathrm{MeV})\end{array}$ & $\begin{array}{c}\text { Neutron } \\
\text { Yield } \\
\left(10^{-6} \mathrm{n} / \mathrm{p}\right)\end{array}$ \\
\hline Ta-181 & 3287 & 99.988 & 0.975 & 0.0319 & 1.472 & 0.345 \\
\hline $\mathrm{V}-51$ & 2175 & 99.75 & 1.564 & 0.637 & 2.044 & 0.264 \\
\hline Te-128 & 723 & 31.69 & 2.052 & 0.137 & 2.543 & - \\
\hline $\mathrm{Mo}-95$ or & 2890 & 15.92 & 2.51 & 0.306 & 2.995 & 1.29 \\
$\mathrm{Se}-80$ & 494 & 49.7 & 2.69 & 0.462 & 3.170 & 1.42 \\
\hline $\mathrm{Sc}-45$ or & 1812 & 100 & 2.91 & 1.556 & 3.374 & 0.412 \\
$\mathrm{Ga}-69$ & 303 & 60.1 & 3.051 & 0.707 & 3.528 & $\ldots$ \\
\hline $\mathrm{Sn}-120$ & 505 & 32.59 & 3.49 & 0.273 & 3.977 & $\ldots$ \\
\hline $\mathrm{Cu}-63$ & 1358 & 69.17 & 4.21 & 1.191 & 4.683 & 2.40 \\
\hline $\mathrm{Cd}-110$ & 594 & 12.49 & 4.757 & 0.450 & 5.237 & $\cdots$ \\
\hline $\mathrm{Mg}-25$ & 922 & 10.00 & 5.266 & 9.10 & 5.675 & $\ldots$ \\
\hline
\end{tabular}

Total yield: $-9.2 \times 10^{-6} \mathrm{n} / \mathrm{p}$. 
Table 4. Target design with Enmax $=50 \mathrm{keV}$.

\begin{tabular}{|l|l|l|l|l|l|l|}
\hline Elements & $\begin{array}{l}\text { Melt. Pt. } \\
(\mathrm{K})\end{array}$ & $\begin{array}{l}\text { Compositin } \\
(\%)\end{array}$ & $\begin{array}{l}\text { Thresh. } \\
(\mathrm{MeV})\end{array}$ & $\begin{array}{l}\text { Neutron } \\
\text { Energy at } \\
\text { Epth(keV) }\end{array}$ & $\begin{array}{l}\text { Max.Proton } \\
\text { Energy } \\
(\mathrm{MeV})\end{array}$ & $\begin{array}{l}\text { Neutron } \\
\text { Yield } \\
\left(10^{-6}{ }_{\mathrm{n}} / \mathrm{p}\right)\end{array}$ \\
\hline $\mathrm{Ta}-181$ & 3287 & 99.988 & 0.975 & 0.0319 & 1.0235 & \\
\hline $\mathrm{Mn}-55$ & 1517 & 100 & 1.028 & 0.356 & 1.072 & $\mathrm{x}$ \\
\hline $\mathrm{Mo}-100$ & 2890 & 9.63 & 1.131 & 0.306 & 1.178 & $\mathrm{x}$ \\
\hline $\mathrm{K}-41$ & 336 & 6.73 & 1.233 & 0.763 & 1.274 & $\mathrm{x}$ \\
\hline $\mathrm{Ru}-101$ & 2523 & 17.0 & 1.349 & 0.142 & 1.396 & \\
\hline $\mathrm{Cr}-53$ & 2130 & 9.501 & 1.41 & 0.529 & 1.4485 & \\
\hline $\mathrm{V}-51$ & 2175 & 99.75 & 1.564 & 0.637 & 1.6056 & \\
\hline $\mathrm{Fe}-57$ & 1809 & 2.2 & 1.648 & 0.541 & 1.69 & \\
\hline $\mathrm{Zr}-94$ & 2125 & 17.38 & 1.699 & 0.208 & 1.7445 & \\
\hline $\mathrm{Zn}-67$ & 693 & 4.1 & 1.81 & 0.434 & 1.853 & \\
\hline $\mathrm{Co}-59$ & 1768 & 100 & 1.887 & 0.582 & 1.929 & \\
\hline $\mathrm{Te}-128$ & 723 & 31.69 & 2.052 & 0.137 & 2.098 & \\
\hline $\mathrm{Cu}-65$ & 1358 & 30.83 & 2.166 & 0.556 & 2.208 & \\
\hline $\mathrm{Cr}-54$ & 2130 & 2.365 & 2.197 & 0.812 & 2.238 & \\
\hline $\mathrm{Mo}-98$ & 2890 & 24.13 & 2.390 & 0.274 & 2.435 & \\
\hline $\mathrm{Mo}-95$ & 2890 & 15.92 & 2.510 & 0.306 & 2.554 & \\
\hline $\mathrm{Se}-80$ & 494 & 49.7 & 2.687 & 0.462 & 2.73 & \\
\hline $\mathrm{Zr}-92$ & 2125 & 17.15 & 2.817 & 0.369 & 2.861 & \\
\hline $\mathrm{Sc}-45$ & 1812 & 100 & 2.909 & 1.556 & 2.945 & \\
\hline $\mathrm{B}-11$ & 2300 & 80.1 & 3.018 & 23.5 & 3.025 & \\
\hline $\mathrm{Ga}-69$ & 303 & 60.1 & 3.051 & 0.707 & 3.092 & \\
\hline $\mathrm{Sn}-120$ & 505 & 32.59 & 3.492 & 0.273 & 3.537 & \\
\hline
\end{tabular}

Total yield: $-2 \times 10^{-7} \mathrm{n} / \mathrm{p}$.

$\mathrm{x}$---- The composition of the isotope is too small to make target, but enriched material might be available for the application. 


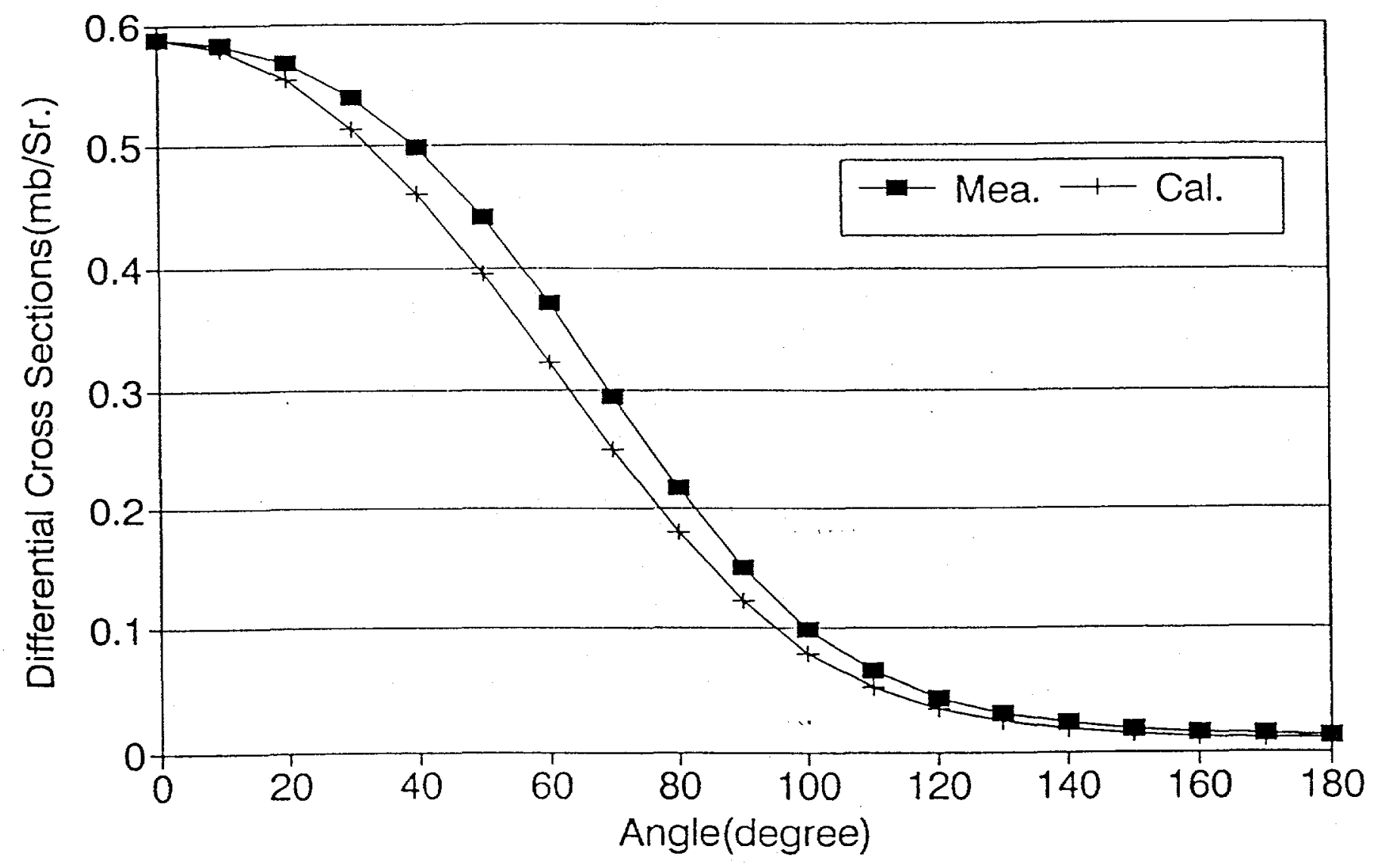

Figure 1. Differential Cross Section of Li-7 for Proton Energyat $1.95 \mathrm{MeV}$. 


\section{Appendix 1}

Brugger, RM., X. Luo, J.F. Kunze, "Targets for the Production of Neutrons from Low Energy Positive ion Accelerators", TRANS. Am. Nuclear Society, 65, p.146 June 1992. 
gists, radiobiologists, and dermatologists on the many technical and scientific tasks that must be resolved before human irials are possible. This paper reviews some aspects of this project.

Neutron capture therapy is a bimodal therapy requiring the delivery of the neutron capture agent to the cancer cells, where it must concentrate to significanly higher levels than in healthy tissue, and the delivery of neutron irradiation to the tumor with suitable neutron beams. Currenuly, NCT with ${ }^{10} \mathrm{~B}$ as the capture agent (BNCT) offers the most promise. The results reported here are based on the ${ }^{10} \mathrm{~B}$ delivery agent boronophenylalanine (BPA). Methods to quantify the BPA $\left({ }^{10} \mathrm{~B}\right)$ in blood and tissue are necessary: These techniques should be sensitive down to at leasi the parts-per-million level, should be suited for rapid and accurate quanification in bulk samples, and. if at all possible, should allow the microscopic determination of ${ }^{10} \mathrm{~B}$ with subcellular spatial resolution. Toxicity and efficacy studies $w i t h$ animals are a necessary prelude to testing a new therapeutic modality in humans and have been completed to a large exient.

Neutron beams for NCT were a major consideration in the original design of the MIT research reactor (MITR) and received further emphasis during the upgrading of this reactor to MITR-11. At the time of the upgrade in the mid-19\%0s. highquality thermal neutron beams were judged to be the most desirable for XCT. Such a beam was constructed with small contamination from fast neutrons and gamma ravs. Fortunately, however. a spectrum shifter was also incorporased into the beam line. which could be used to provide an intense source for an epithermal beam. Epithermal beams have deeper useful penetration in tissue, $708 \mathrm{~cm}$ versus 3 to $5 \mathrm{~cm}$ for thermal beams. For successful brain-cancer therapy, it is believed that it must be possible to achieve a therapeutic effect at all depths in the brain. This requites epithermal neutrons. An epithermal beam has been consiructed and implemented on the MITR-1l medical beam line. which permits BNCT with therapeutic effectiveness at any location in the human brain. Figure 1 shows the MITR-11, the niedical room below the reacior core, and the beam line with ine epinhermal neutron filter installed. The filter uses sulfur and aluminum to preferentialk remove fasi neutrons and to pass epithermal neutrons. Cadmium ssced 10 remove thema! heutrons and a final shicid of bismuth remoles unwanted samma ravs.

Boton quantization and imaşing at the microscopic lacl are based on promp gamma analysis and on track eich auroradiography. A prompr gamma facility has been constructed based on a diffracted beam. This unusual approach provides a slow neutron current in the sample that is considerath lower than can be achicved by a dires reactor heam. How ever. the backgrourd at the solid-state detevor is greatly decreased by using Bragg diffraction. This pernits the optimum placement of the germanium detector. and the increased solid angle makes up for the intensity lost in the Brage diffraction. Furthermore. the lower intensity beam with steasly redued fast neutron and background components sreally facilitates aciess to the sample position with minimal sthiclding. Very small samples, e. $10^{-2} \mathrm{~cm}$, with low concentrations of is $\mathrm{B}$ are ana. lyzed by quantiative neutron irack etch auloradiography (QNR). The QNR is cross-alitrated with the prompt samma.

To determine where the " $\mathrm{B}$ is absorbed whin the cell siructure, we have developed a unioue technique. high-resolution autoradiography (HRA). This HR.A has adequate resolution to determine the spatial distriturion of " $\mathrm{B}$ on the subcellulat level, a critical element in the assessment of neutron capture effectiveness. The resolution is $2103 \mu \mathrm{m}$, and the sensilivity is betler than 1 ppm.

A series of small-animal experiments has been carried oul to asses the toxicity of BP.A and to determine the efficacy of neutrons plus BPA as compared to conventional therapy modalities. Toxicity and biodistribution studies of the BPA in a limited number of human volunteers have also been completed.
2. Targets for the Production of Neutrons from Low-Energy Positive Ion Accelerators, Robert M. Brugger, * Xunshan Luo, Jay F. Kunze (Lini of Missouri-Columbia)

\section{INTRODLCTION}

To produce neutrons for neutron capture therapy at a hospital, a compact positive ion accelerator. such as a radis-frequency quadrupole machine, with a moderator blanke: would be more readily accepted than a reactor with a moderator. Linfortunately, designs to date of accelerator-based epithermal neutron beams fall short of similar beams from reactors of a few megawatts. To try to identify improvements, we have araluated many neutron-producing reasions. The $L i(p . n)$ and ${ }^{3} \mathrm{H}(p, n)$ coninue to be the most promising for neuron yield, but both have troubles with target desien

For the Li $(p, n)$ reaction. the threshold is $1.88 \mathrm{Mel}$. hut protons uf to $2.5 \mathrm{Mel}$ can he used w ith a thick target teforo gamma rays are produced by excitation of the first excited state in $\mathrm{Be}$. 11 e calculate the vield of neutrons to be $1.48 \times 10^{-6}$ neutrons per proton. However, for this larger, three-tourths of the heas is produced by proions belom the threshold. At $2.5 \mathrm{Mel}$. the maximum neutron enery is $5.0 \mathrm{kel}$, and a moderator must surround the tarset io reduce the energies of the neutrons to less than - $10 \mathrm{kel}$. This moderator significanth reduces the beam current of epithermal neutrons so that proton currents of $20 \mathrm{~mA}$ or more nuss the ased io produce an epithermal beari ci $>1 \times 10^{4} \mathrm{n} \mathrm{cm}^{2}$. . Lithium or hidrogen iargets that can withstand $50 \mathrm{kll}$ of heat ate difficult to desien. $1 \mathrm{l}$ is suggested thal a larget of lithium on a high-conducivits backing would have to be $15 \mathrm{~cm}$ in diameter to spread this heat load.' Such sizes compromise the moderator design. li a target could he designed to more effenthely use the protons in the energy range where neutrons ate produied. these larget design problems might be orercome.

\section{MLLTIPLE-LAYER TARGETS}

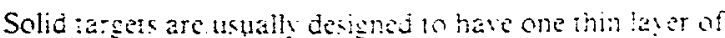

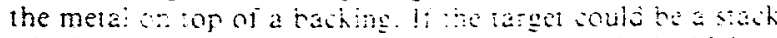

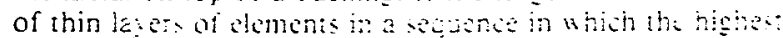

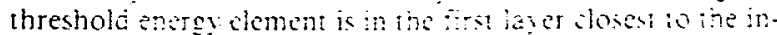

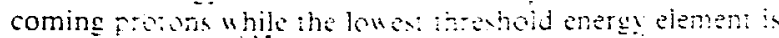
in the las: ater one might uxe mose of the proion seners? w increase the neutron yield and ber. of the profon ense: unconstruch by merely produste hea. Each layer bould be thin ard ake advantage of the propo energy in a range where that material had a reavonie aros rection for the neutron-rovducing reaction.

We he examined the literature ior arious reations that

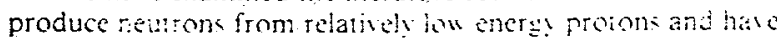
identifiec $t^{-}$uch reacions bolow $20 \mathrm{VIN}$. and 16 of inese aro

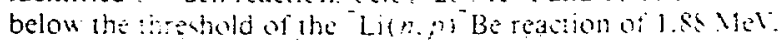
Unfortunateh, the neutron veld for many of these later ieactions is whewn from ihe literatus and for thos whin ate known. the veld is usually quite mall compared to the "Li re-

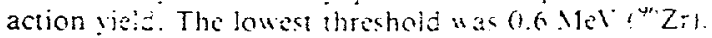

Tahle 1 provides an example a a layered lateel design in which se: malerials. including " $L$. have been arranged in a multiple arept laver arrangement. The maximum proon beam

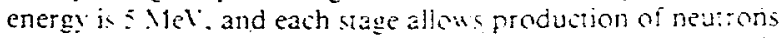
up 10800 hel before the nex iarset material is iniroduced. The overal! yield from this arrangement is zoro more than the yield from 2 2.5-11el beam on "Li. This would not seen to be a useful gain. ohtaining only $25 \sigma_{0}$ more production from a doubling of the proton beam power. Enhancing just a $\mathrm{Li}$ target (2.5-1) l maximum proron energy) to lower energies

*Currenla at Brookhaven National Laboratory 
TABLE 1

Mulniple-Layer Tareer Denign

\begin{tabular}{|c|c|c|c|c|}
\hline Maicrial & $\begin{array}{l}\text { Mell } T \\
(k)\end{array}$ & $\begin{array}{c}\text { Theshold } \\
\text { Proton, } E \\
\text { (Ael) }\end{array}$ & $\begin{array}{c}\text { Maximum } \\
\text { Proton } \\
\text { Energy } \\
\text { (Mel) }\end{array}$ & $\begin{array}{l}\text { Neutron } \\
\text { lield }\end{array}$ \\
\hline Enriched ${ }^{*} \mathrm{Z}_{r}$ & 2325 & 0.606 & 1.0 & $6^{\mathrm{a}}$ \\
\hline${ }^{181} \mathrm{Ta}$ & 3287 & 0.98 & 1.7 & 5.9 \\
\hline${ }^{\prime} \mathrm{Li}$ & 454 & 1.88 & 2.51 & 148 \\
\hline Enriched ${ }^{*} \mathrm{Se}$ & 494 & 2.69 & $3:$ & 3.5 \\
\hline Enriched $: S n$ & 505 & 3.49 & 4.28 & $6^{a}$ \\
\hline Enriched ${ }^{6.3} \mathrm{Cu}$ & 1358 & 4.2 & 4.98 & $\delta$ \\
\hline \multicolumn{4}{|c|}{ Toral yield $\left(10^{-t} \mathrm{n}\right.$ fl } & 178 \\
\hline
\end{tabular}

${ }^{a}$ Estimated sield: no data found.

by adding a "A: Ta layer and a "Zr laser bnder the Li layer enhances the ouipui by only $80^{\circ}$.

\section{REACCELERATED PROTON TARGFTS}

Another poiental solution for incrasing the yield whout increasing the nonproductive proton beam energy is to construct the targa in layers of marerial sepataled by racuum and reaccelerate the protons between layers. such as with $100 \mathrm{keV}$ potential differences. Each target layer would have just the appropriate thickness for the protons a fose on the order of $100 \mathrm{kel}$ of energy. These layers could continue to be added until the reacceleration did not bring the protons back to the threshold. It is best 10 have as much target maierial as possible see the higher energy protons because inere the total cross section and the yeld of neutrons are the greatest. Target thickness for a given tne:y loss is another adventage, beins - 1500 more at $2.5 \mathrm{M}$ than at 1.88 .1 el for hitum. Howeler, the thickness of such a lithium layer is mly 35 wh for a $200-\mathrm{keV}$ energy loss at the 2.4-MeV level. Clewer larged desisn, such as by use of a small honeycomb, is requited to icmove the heat generated without sacrificing any of the prown energy above $1.88 \mathrm{MeV}$ in materials other than lithium. The benefits are worth seeking, however, because or cry $1(0)-k c l$ reaceleration. especially in the $2.5-\mathrm{MeV}$ region, will chlathe the larget output by $-200_{0}^{\circ}$.

1. T. J. DOLAN. Idaho National Enginecring Laboratory. Private Communication.

3. Potential Impact of Low-Enriched Uranium Research Reactor Core Conversions on Irradiation Facilities for BNCT, Lisa A. Heimberger, Tunc Aldemir (Ohio State)

\section{INTRODLCTION}

A critical requirement for boron neutron capiure therapy' (BNCT) is a strong source of thermal $(<1-24)$, epithermal (l-el to $10-\mathrm{k} 2 \mathrm{l})$ neutrons. The currenly avalade neutron sources with sufficient intensity are revearch and :est reactors. Since the neutrons generated in nudear reator cores cover a wide spectrum of energies and the stecticenes of $B N C T$ strongly depends on how well the fast $1>10-k e l$, zeutron dose to healhy issue is minimized, the core beutron spotrum is an important consideration in the desigr of an iratiation facility for B:CT.

A larse number of research and iesi reacrors th the world use highly enriched uranium (HEL) fuels. In vien of the restriction on the export of HEL from the Lni:- Siates and also the 1986 L.S. Nuclear Regulator: Commission ruling. these redurs are in the process of being converiez 00 use lowenriched uranium (LEL) fuels. The conversion foress usually lead io wore spectrum hardening di.e. . inif :o tigher neutron energic:1. The objective of this paper is to preser: the results
Top View

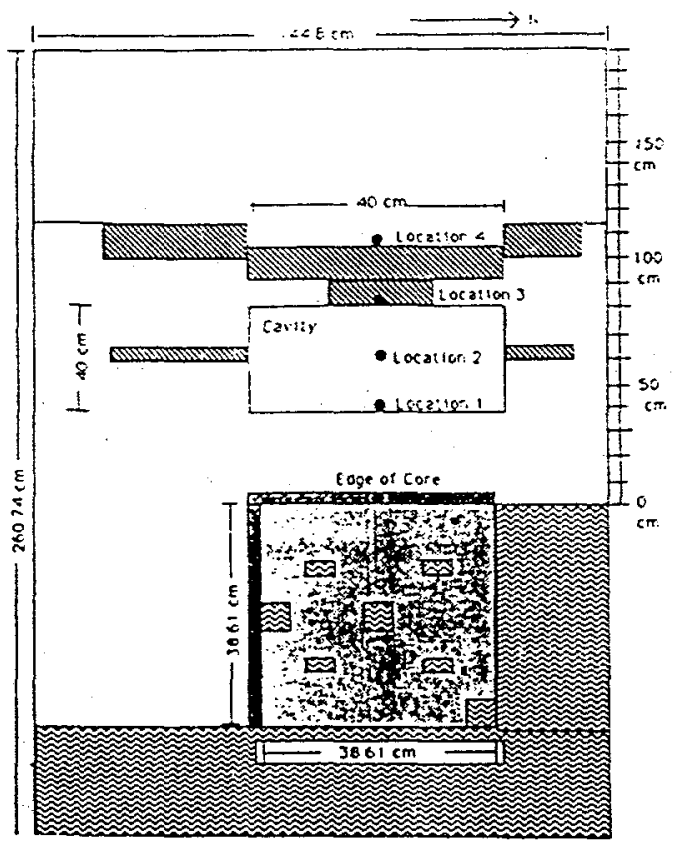

Axial Cut
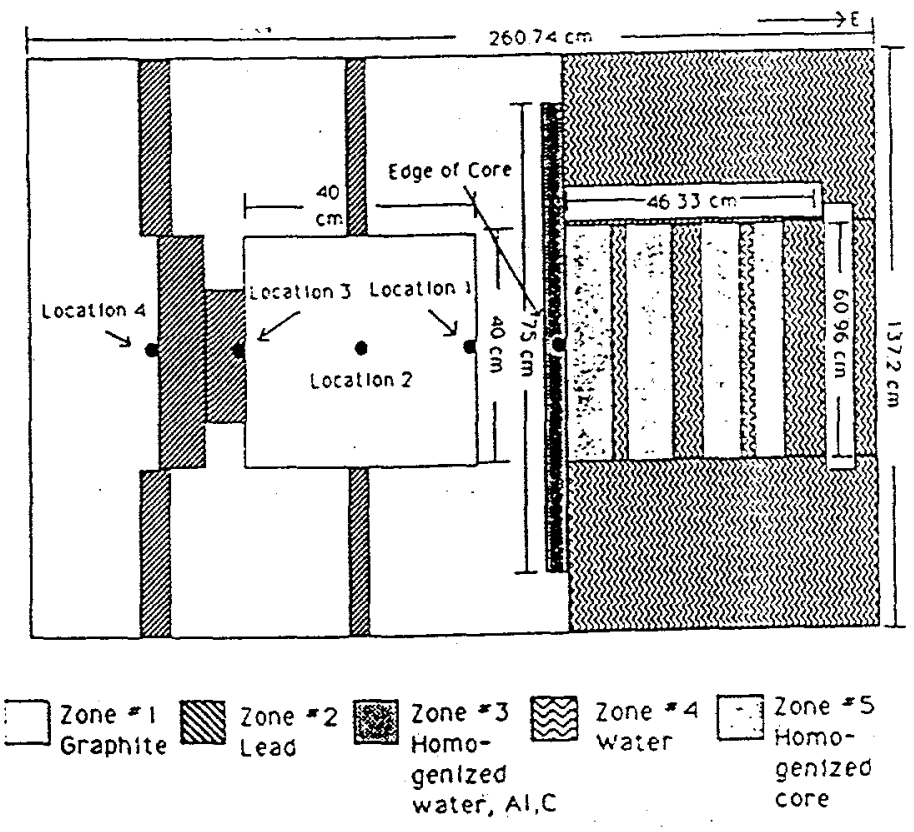

Fig. 1. Facility model for calculations. 


\title{
Appendix 2
}

\section{LOW ENERGY ACCELERATOR-BASED NEUTRON SOURCES}

\section{FOR NEUTRON CAPTURE THERAPY}

\author{
Terry H. Wu, ${ }^{I}$, Robert M. Brugger, and Jay F. Kunze \\ Nuclear Engineering Program \\ University of Missouri \\ Columbia, MO 65211 \\ 1) Currently at St. Louis University Hospital \\ Rad. Therapy Dept., Vista e Grand Blvd. \\ st. Louis, MO 63110
}

\section{INTRODUCTION}

Neutron beams for neutron capture therapy (NCT) have been studied by a number of investigators, $1,2,3$ using high flux research reactors as the source of neutrons. There are very few research reactors in the world, probably less than ten, that can meet the conditions of both flux intensity and neutron energy spectrum. Hence the availability of NCT for patients with malignant brain tumors would be quite limited, even if all of these reactors would be able to accommodate the necessary beam design and hospital room atmosphere into the operational program.

For a number of years it has been suggested that serious design work should be undertaken to develop accelerator-based sources for the neutrons, using compact accelerator designs. The relatively new $R F Q$ (radiofrequency-quadrupole) linear accelerators have the promise of achieving this objective.

This study investigates the optimization of the moderator and reflector system that would be used between the accelerator and the patient. The study is similar to that of Blue et al at ohio state University, and Dolan ${ }^{4}$ at INEL, but goes further in attempting to optimize the useful neutron flux for boron NCT with respect to the unwanted dose from neutrons and gamma rays. This study also investigates both the $\mathrm{Li}-7(\mathrm{p}, \mathrm{n})$ and $\mathrm{H}-3(\mathrm{p}, \mathrm{n})$ proton accelerator target reactions. Though these two targets are studied separately, and each would involve an entirely different target design, a combination target of tritiated lithium hydride deserves to receive attention in future designs.

The yields from the targets were calculated from the differential cross sections and stopping powers in the literature, assuming thick targets for the incident protons. The yields were divided into five angular groups, which were used as input to the MCNP Monte carlo computer code. Neutron fluxes, neutron doses, and gamma doses were calculated at the patient position (skuli) and at a tumor at various depths. 
The basic system design that was eventually adopted, after a number of design iterations, is shown in Figure 1 . The moderator adopted was $20 \mathrm{~cm}$ of $\mathrm{BeO}$, for the Li reaction, and $34 \mathrm{~cm}$ of $\mathrm{Al}_{2} \mathrm{O}_{3}$ for the ${ }_{\mathrm{H}}$ reaction. The moderator and the $3 \mathrm{~cm}$ diameter accelerator vacuum (drift) tube were surrounded by the reflector of $\mathrm{MgO}$ for the $\mathrm{Li}-7$ reaction, $\mathrm{Al}_{2} \mathrm{O}_{3}$ for the tritium reaction. These selections were made on the basis both of maximizing desired neutron flux and of minimizing other neutron and gamma doses (see following section). Total diameter of the outside of the reflector was $85 \mathrm{~cm}$, and it extended $33 \mathrm{~cm}$ back along the accelerator drift tube.

The goal of this design was to produce neutrons, at the patient, predominantly in the energy range of $1 \mathrm{eV}$ to $10 \mathrm{keV}$. our studies, and those of other investigators, had shown that this range would optimize the treatment for tumors at a 3 to $7 \mathrm{~cm}$ depth from the surface of the skull. The reference tumor used for the calculations was $6 \mathrm{~cm}$. It was assumed that the tumor contained $30 \mu \mathrm{g}$ of boron-10 per gram of tissue, and that there was a 10:1 ratio between tumor and healthy tissue, i.e. the healthy tissue had $3 \mu \mathrm{g} / \mathrm{g}$ concentration of $\mathrm{B}-10$.

The neutron source reactions studied were from the two reactions shown in Table 1 . The protion energy on target was limited to a maximum value that would not produce neutrons above nominally $1 \mathrm{MeV}$, since higher energy neutrons are much more difficult to moderate down to the desired intermediate energy (epithermal) neutron energy range desired at the patient position. Since the threshold proton energy for the two reactions is not the same, the needed maximum proton energy differs between the two reactions, being only $1.77 \mathrm{MeV}$ for the tritium target, but $2.5 \mathrm{MeV}$ for the Li-7 target. Furthermore, the neutron yield for the hypothetical pure tritium target is nearly twice that of a pure Li-7 target. However, the target design to obtain the full utilization of the proton beam is not as obvious for the tritium target as it is for the lithium target.

Table 1. - The neutron-producing proton target reactions employed in the design, and the limiting conditions.

\begin{tabular}{|c|c|c|}
\hline & $\mathrm{H}^{3}(\mathrm{p}, \mathrm{n}) \mathrm{He}^{3}$ & $\mathrm{Li}^{7}(\mathrm{p}, \mathrm{n}) \mathrm{Be}^{7}$ \\
\hline Q-Value (MeV) & -0.764 & -1.645 \\
\hline Threshold Energy (MeV) & 1.019 & 1.881 \\
\hline Neutron Energy (MeV) a threshold & d 0.064 & 0.029 \\
\hline Incident Proton Energy (MeV) & 1.77 & 2.50 \\
\hline Maximum Neutron Energy (MeV) & $1.00-4$ & $0.787-4$ \\
\hline Total neutron yield, $\mathrm{n} / \mathrm{p}$ & $2.54 \times 10^{-4}$ & $1.48 \times 10^{-4}$ \\
\hline
\end{tabular}

\section{DOSE RESULTS}

All dose calculations were done with reference to a thin tissue-equivalent cell at the patient irradiation position, used to determine the neutron and gamma fluxes that would be present at the surface of the skull. The intent was to optimize the desired intermediate neutron flux, but also to minimize the doses to the patient from the other neutrons and gamma rays. 
The selection was done on a somewhat arbitrary basis, using plots similar to that of Figure 2 , which shows the selection of reflector material for the lithium target reaction. The dotted lines indicate the minimum acceptable intermediate neutron flux, and the minimum ratio of that flux to total neutron dose to healthy tissue.

The gamma dose was an item of major concern, and this was minimized by adding a small amount of Li-6 neutron absorber to both moderator and reflector. The Li-6 absorbed the thermal neutrons, reducing their direct dose, and also reduced the radiative capture in the moderator and reflector materials, thus reducing the gamma dose. Figure 3 is a plot which resulted in the selection of 0,05 atom percent as the "optimum" amount of Li-6 poison to recommend.

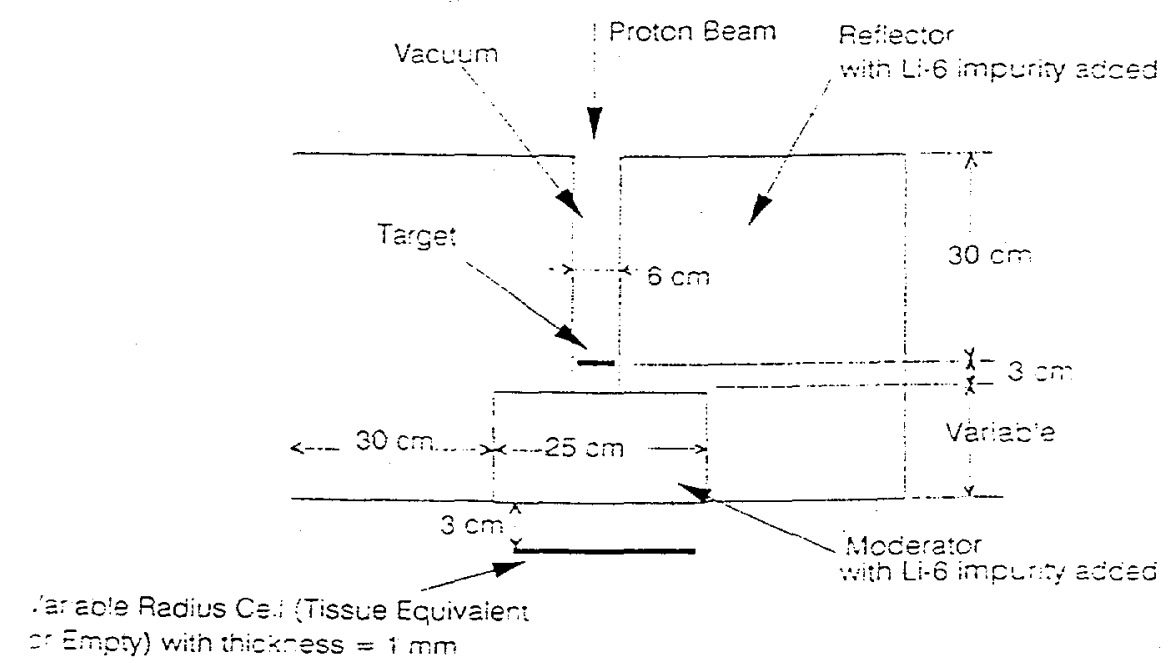

Figure 1. Moderator-Reflector Assembly Design. Moderator is Beo. Reflector is $\mathrm{MgO}$ for Li-7 target and $\mathrm{Al}_{2} \mathrm{O}_{3}$ for the tritium target.

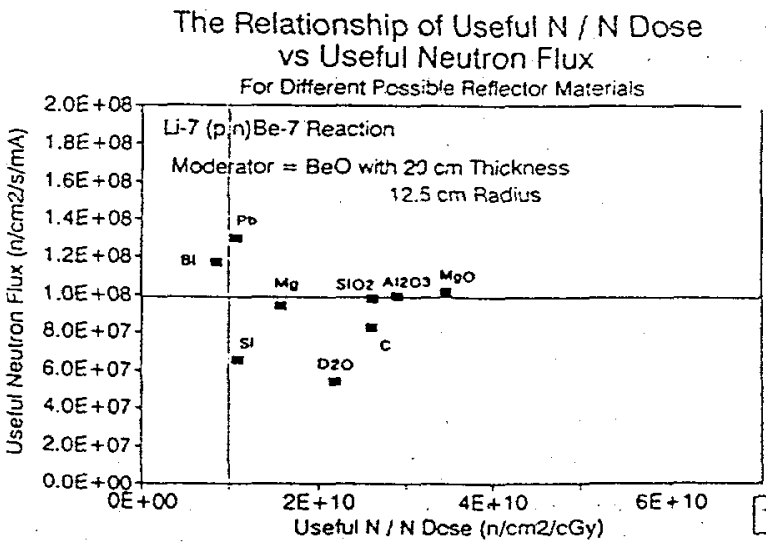

Figure 2. Selection of reflector material for Li-6 target.

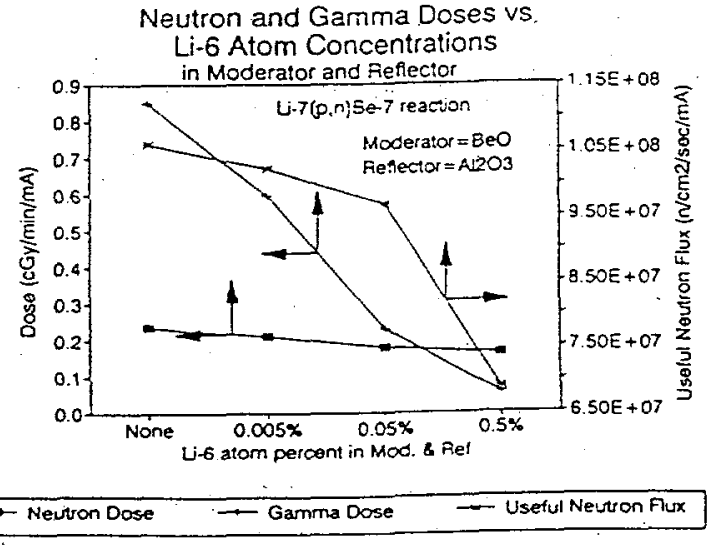

Figure 3. Selecting the amount of Li- 6 poison to use. 
Table 2 lists the overall results from the design, for the desired (useful) intermediate energy neutron flux, and the undesirable doses to healthy tissue. Results are quoted with respect to one milliampere of proton beam on the target. Present RFQ machine technology has achieved proton beam currents of a few milliamps, with up to 20 milliamps believed to be achievable with current state-of-the art operation. 6

These beam currents would give the desired treatment, $2000 \mathrm{CGY}(\approx 5000 \mathrm{CSV}$ or Rem) to a tumor having $30 \mu \mathrm{g}$ of $\mathrm{B}-10 / \mathrm{g}$ of tissue, in approximately 45 minutes for the $\mathrm{H}-3$ target (55 minutes for Li-6 target). This is a factor of 4 to 5 times longer than for beams designed for some of the higher powered research reactors, such as that at the University of Missouri. However, the 45 minute treatment period appears to be within the tolerable range for a patient treatment time.

TABLE 2 - Calculated Results, per mA of Proton Beam

$\mathrm{H}-3$ target $\mathrm{Li}-7$ target

AT PATIENT IRRADIATION POSTTION IN AIR

Total Neutron flux $\phi\left(\mathrm{n} / \mathrm{cm}^{2} \mathrm{sec}\right)$

Epithermal Neutron flux $\phi(1 \mathrm{eV}-10 \mathrm{keV})$

Neutron dose in cGy/epithermal $\mathrm{n} / \mathrm{cm}^{2}$

Gamma dose in cGy/epithermal $\mathrm{n} / \mathrm{cm}^{2}$

Thermal neutron $\phi\left(\mathrm{n} / \mathrm{cm}^{2} \mathrm{sec}\right)$

Total dose to tumor in cGY/minute

.1. $29 \mathrm{E}+8$

1. $10 \mathrm{E}+8$

4. $1 E-11$

2. $8 \mathrm{E}-11$

$1.14 \mathrm{E}+8$

2.23
1. $31 E+8$

$0.94 \mathrm{E}+8$

$4 \cdot 3 E-11$

2. $7 E-11$

$1.00 \mathrm{E}+8$

1.78

AT $6 \mathrm{~cm}$ DEPTH TUMOR WITH $30 \mu \mathrm{g} B-10 / \mathrm{g}$ Of TISSUE

Fraction of dose from $B-10(n, \alpha)$

Fraction of dose from Fast neutrons

Fraction of dose from $N-14(n, p)$

Fraction of dose from gammas

"Advantage Depth"*

$65 \%$

$4 \%$

$1 \%$

$30 \%$

$9 \mathrm{~cm}$

$67 \%$

$5 \%$

$1 \%$

$27 \%$

* Depth at which B-10-caused dose is equal to the

$8 \mathrm{~cm}$ neutron and gamma doses to the tumor.

\section{REFERENCES}

1. F.J. Wheeler, D.K.Parson, B.L.Rushton, and D.W.Nigg, Epithermal Neutron Deam Design for Neutron Capture Therapy at the Power Burst Facility and the Brookhaven Medical Research Reactor Epithermal Neutron Source", Nuclear Technolog:, 92, 106 (1990)

2. R.G. Fairchild, J.kalef-Ezra, S.R.Saraf, S. Fiarman, E.Ramsey, L.Wielopolski, B.H.Laster, F.J.hineeler, "Installation \& Testing of an Optimized Epithermal Neutron Beam at the Brookhaven Medical Research Reactor," in Neutron Beam Design. Dev.. and Perf.for Neutron Capture Therapy, O.K.Harling, ed.. Plenum Press, N.Y.(1990)

3. R.M. Brugger \& W.H. Herleth, "Intermediate Energy Neutron Beams from the MURR,", op.cit, page 153

4. C.K.C.Wang, T.E.Blue, R.Gahbauer, "A Neutronic Study of an Accelerator-based Neutron Irradiation Facility for Boron Neutron Capcure Therapy," Nuclear Technology, 84, 93 (1989)

5. T.J.Dolan et al, Idaho National Engineering Lab, EG\&G, Inc., internal report, private communication, (1989)

6. T.P.Wangler, J.E.Stovall, T.S.Bhatia, C.K.Wang, T.E.Blue, R.A.Gahbauer, "Conceptual Design of an RFQ Accelerator-based Source for NCT", Proceedings of the 1989 IEEE PArticle Accelerator Conf. Accelerator Science and Technology, Chicago, IL, CH2669-0, 678 (1989) 


\title{
Appendix 3
}

\section{RESULTS OF BENCHMARK EXPERMMENT OF ACCELERATOR/MODERATOR CONEIGURATION FOR BNCT - USNGG RFQ ACCELERATOR}

\author{
Jay F. Kunze a \\ Rajat Kudchadker ${ }^{\text {a }}$ \\ Jianbin Luo ${ }^{a}$ \\ Y-W (Frank) Lo ${ }^{a}$ \\ Frank Harmon ${ }^{b}$
}

a Nuclear Engineering Program, University of Missouri, Columbia, MO 65211 (314) 882-3550

${ }^{b}$ Dept. of Physics, Idaho State University, Pocatello, ID 83209 (208) 236-2350

KEYWORDS: BNCT, ACCELERATOR, BENCHMARK

\begin{abstract}
A number of design studies involving Boron Neutron Capture Therapy (BNCT) have been done using the MCNP code. There is always the question of how accurate are these studies, and do they conform to reality. A relatively simple benchmark experinent has been conducted using the $2.0 \mathrm{MeV} R \mathrm{RQ}$ accelerator at Idaho State University. Result of the measurements that can be considered reliable enough to be used as a benchmark are given, and a discussion of the need for additional reliable measurements is included.

\section{NTTRODLICTION}

Following an extensive computer design effort using the MCNP code : it was decided that the results that had been obtained needed to be verified by a benchmark experiment of similar dimensions and similar materials. Calculations alone may or may not represent reality, and since benchmarks of this type had never been performed, it was decided to use the VandeGraff generator at Idaho State Universitg to perform a henchmark experiment of relatively simple geometry. The initial attempts in 1992 were relatively unsuccessful, because of a very unsteady beam. With significant arcing, and hence great uncertainty in correlating beam time and average energy with the measured neutron and ganma fluences. Part of the problem was attempting to run a $2.0 \mathrm{MeV}$ VandeGraff machine at as high an energy as possible (some runs approached $2.3 \mathrm{MeV}$ ) so as to get closer to the optimum proton energy. nominally $2.5 \mathrm{MeV}$. At this energy the neutron yields are the highest, while the gamina contamination is relatively low. At $2.378 \mathrm{MeV}$ proton energy; the product Be-7 nucleus has a threshold of producing its first excited state, from which a $430 \mathrm{MeV}$ gamma ray is emitted. Also, the maximum neutron energy is $0.787 \mathrm{MeV}$, which allow's for not too large of a spread of neutron energy from the proton target, and makes moderating the system to obtain maximum epithermal flux ( $1 \mathrm{eV}$ to $30 \mathrm{keV})$ a bit more successful than from a reactor spectrum, for instance.
\end{abstract}

As plans to return and perform more experiments with the VandeGraff generator were being considered, it became apparent that even afier a complete reconditioning of the unit, smooth, steady state 
operation much over $2.0 \mathrm{MeV}$ was going to be very uncertain. Consequently, a request was made to the INEL for permission to use the newly installed $2.0 \mathrm{MeV}$ RFQ generator (Figure 1), which had been purchased by the INEL and placed at Idaho State University. It appeared that instead of an equivalent 4 microamps total proton current on target, the maximum possible from the VandeGraff, over ten times as much equivalent steady state yield could be obtained with the pulsed RFQ. The stability of the proton beam was indicated to be excellent, in both current and energy.

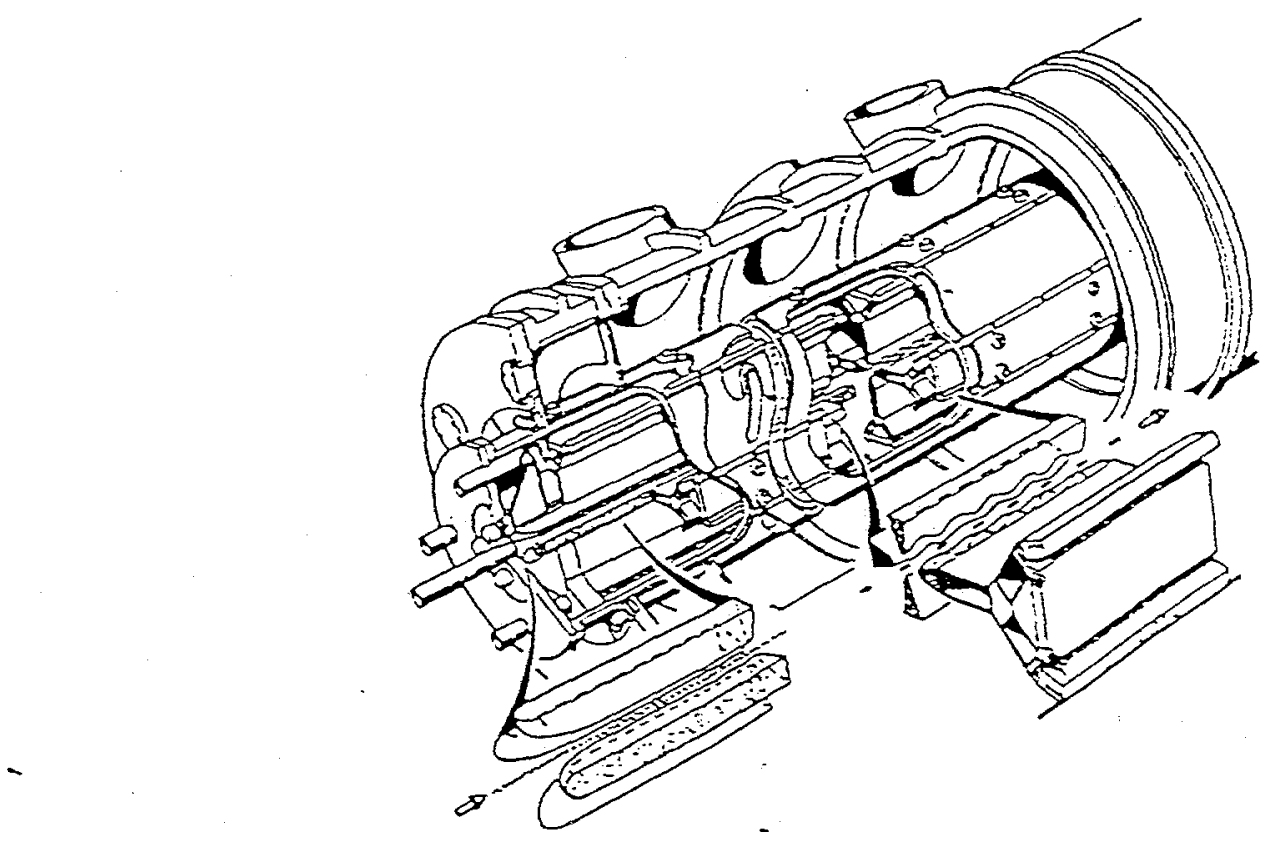

Figure 1: RFQ Positive Ion Accelerator (Los Alamos Design)

\section{ACCELERATOR BEAM CHARACTERISTICS}

The pulsed RFQ accelerator, (manufactured by AccSys Technologies Model PL-2) was operated in a direct linear beam mode (no magnetic deflection) through a long drift tube, onto a lithium target. The resulting reaction $\mathrm{Li}-7(\mathrm{p}, \mathrm{n}) \mathrm{Be}-7$ produced neutrons that spead forwido into a heavy water moderator, and at other angles into an aluminum oxide reflector.

Neutron yield is a very strong function of proton energy (Figure 2. calculated from cross section data in Reference 2) near the $2.0 \mathrm{MeV}$ range. Hence, conducting a benchmark based on proton current would leave a major concern about the actual proton energy'. Furthermore, the structure of the machine with its long drift tube, made aiming of the beam and directing it onio the lithium target very difficult. Finally, the targets used were natural lithium, not lithium-7. and hence maximum neutron production could not be expected. At $2.0 \mathrm{MeV}$, the maximum neutron energy produced is $0.228 \mathrm{MeV}$ in the laboratory system. 


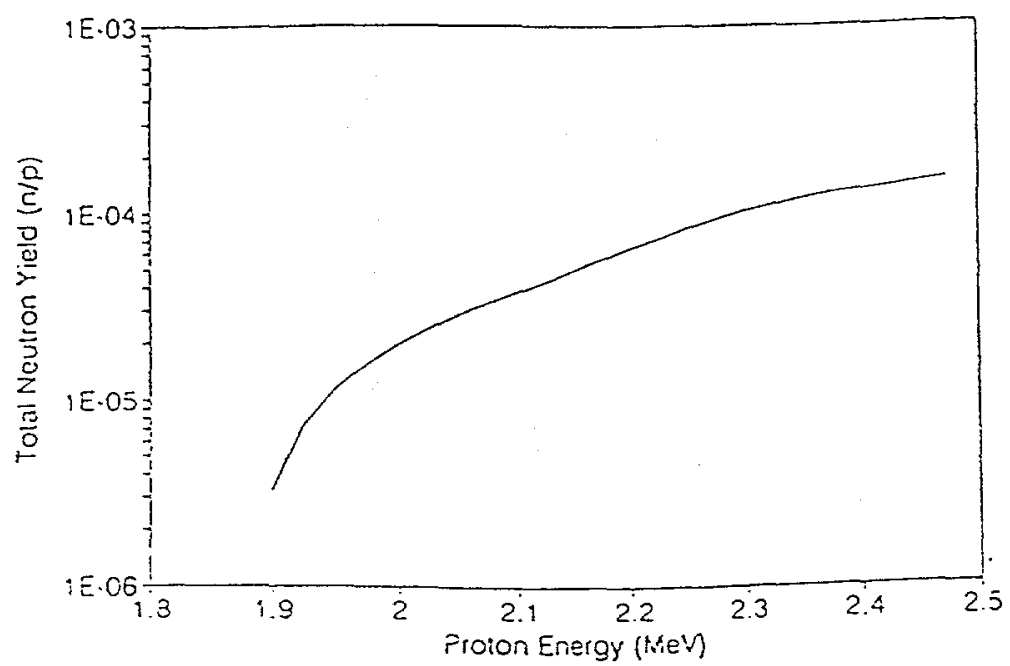

Figure 2: Neutron Yield as a Function of Proton Energy onto Li-7 Target

It was decided that the benchmark could not effectively include the proton beam production of neutrons, because of the various uncertainties. Fortunately, the $\mathrm{Be}-7$ produced in the target reaction allows for neutron production to be measured after the fact. The Be-7 remaining has a half life of 53.29 days, and decays with a $478 \mathrm{keV}$ gamma, with a branching ratio of $10.39 \%$. (See Figure 3.) Each benchmark run was made with a rew target, and the target material was collected after each run and counted in an absolute gamma spectrometer (intrinsic germanium crystal) to determine the activity at shutdown. Runs were typically one hour in length.
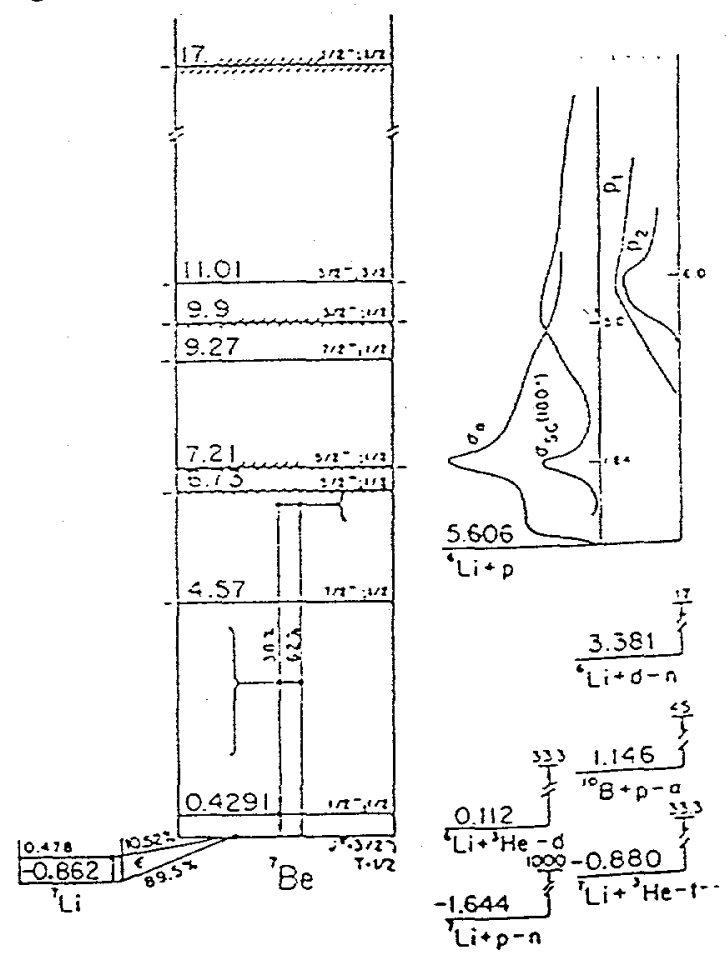

Figure 3: Be-7 Decay Scheme, used for determining absolute neutron production 
Typical beam characteristics were as follows:

$\begin{array}{ll}\text { Pulsing Rate: } & 119 \mathrm{~Hz} \\ \text { Pulse width } & 60 \mathrm{microseconds} \\ \text { Nominal pulse current* } & 10 \mathrm{~mA} \\ & \\ \text { giving an effective "duty cycle" of } 0.0070, \\ \text { and an effective steady state current of } 0.070 \mathrm{~mA}=70 \text { microamps. }\end{array}$

*However, the current was measured with a Faraday cup about $80 \mathrm{~cm}$ from the target. Beam alignment was a critical parameter (discussed in the section on RESULTS), and the Faraday cup measurement may be much higher than the current that reached the active area of the target.

This effective steady state current was about 18 times what could have been obtained with the VandeGraff generator.

\section{DESCRIPTION OF EXPERTIENT}

The geometry chosen was similar to that of the basic computer study conducted by one of the authors', essentially the same as that tried in the earlier benchmark experiment, ${ }^{4}$ and also similar to the design adopted in an earlier study by Blue and associates at Ohio State University. ${ }^{4}$ The benchmark configuration included several minor modifications, primarily in the thickness of the heavy water moderator used between the target and the phantom (patient). Thicknesses of both 10 and $12.5 \mathrm{~cm}$ of heary water were used, consisting of cylinders of $\mathrm{D} 2 \mathrm{O}$ liquid, $14.5 \mathrm{~cm}$ in diameter, encased in a thin layer of plastic. The moderator, and parts of the beam drift tube, were surrounded by aluminum oxide reflector. The referenced work ${ }^{1}$ had actually deternined that berillium oxide was a slightly superior moderator to heavy water for the accelerator-BNCT application using the $L i-7(p, n) B e-7$ reaction, and that magnesium oxide was a superior reflector. These decisions had been made on the basis of neutron yield, and of a high ratio of useful ( $1 \mathrm{eV}$ to $30 \mathrm{keV}$ ) flux to both fast neutron flux and gamma flux at the patient location. Thermal neutrons were virtually eliminated by adding $0.5 \%$ ti to the reflector for those design studies. The Li-6 poison was not included in the reflector of the benchmark, however, because of cost consideraticns.

Figure 4 shows a cross sectional sketch of the moderator reflector arrangement. The aluminum oxide reflector consisted of trapezoidal blocks having a block density of $2.576 \mathrm{gm} / \mathrm{cc}$. Because cf $\leqq a p s$ in the blocks, the effective overall density was somewhat less than the block density. A value of $2 . \Sigma \mathrm{gm} / \mathrm{cc}$ was used in the MCNP computer model of the experiment. Figure 5 shows two photographs of the arrangement. Though somewhat crude, as to the outer surface smoothness, the effective overall density in the regions near the beam rube, moderator, and phantom are believed to be effectively represented by $2.5 \pm 0.15 \mathrm{gm} / \mathrm{cc}$ of aluminum oxide. 

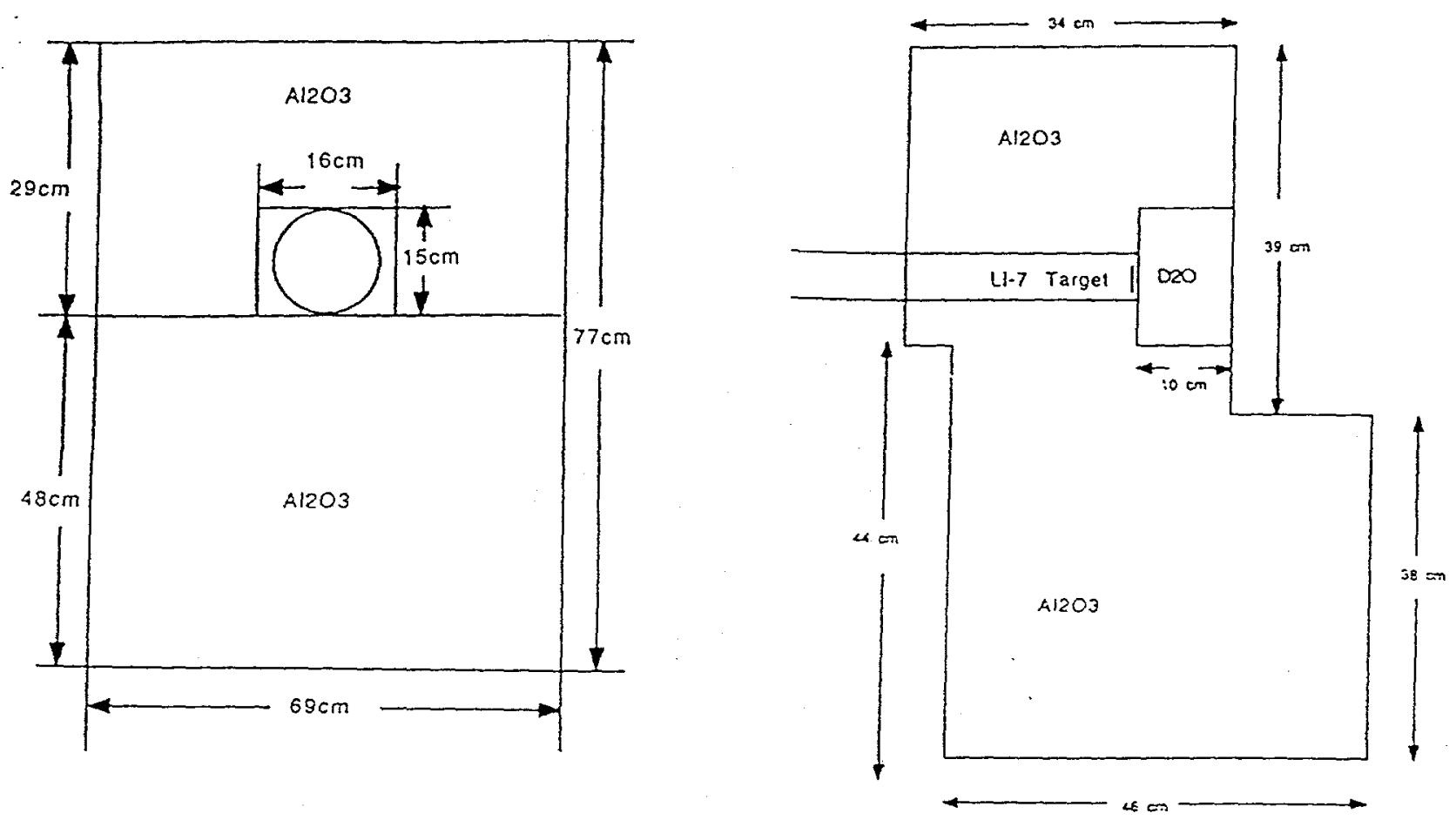

FRONT VIEW OF BNCT SETUP

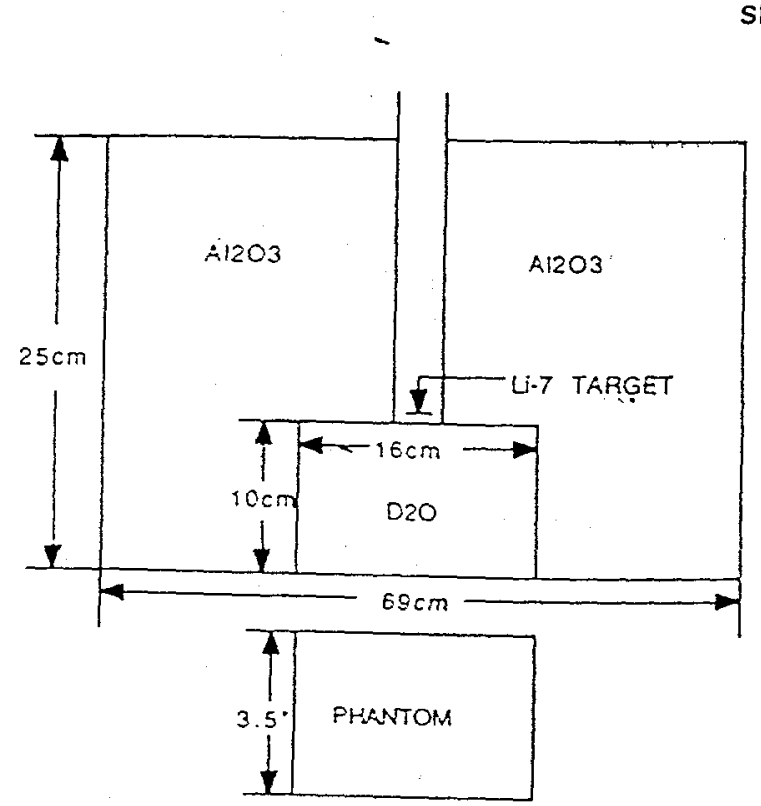

TOP VIEW OF BNCT SETUP

Figure 4: Moderator-Reflector Arrangement for the Benchmark Experiment 

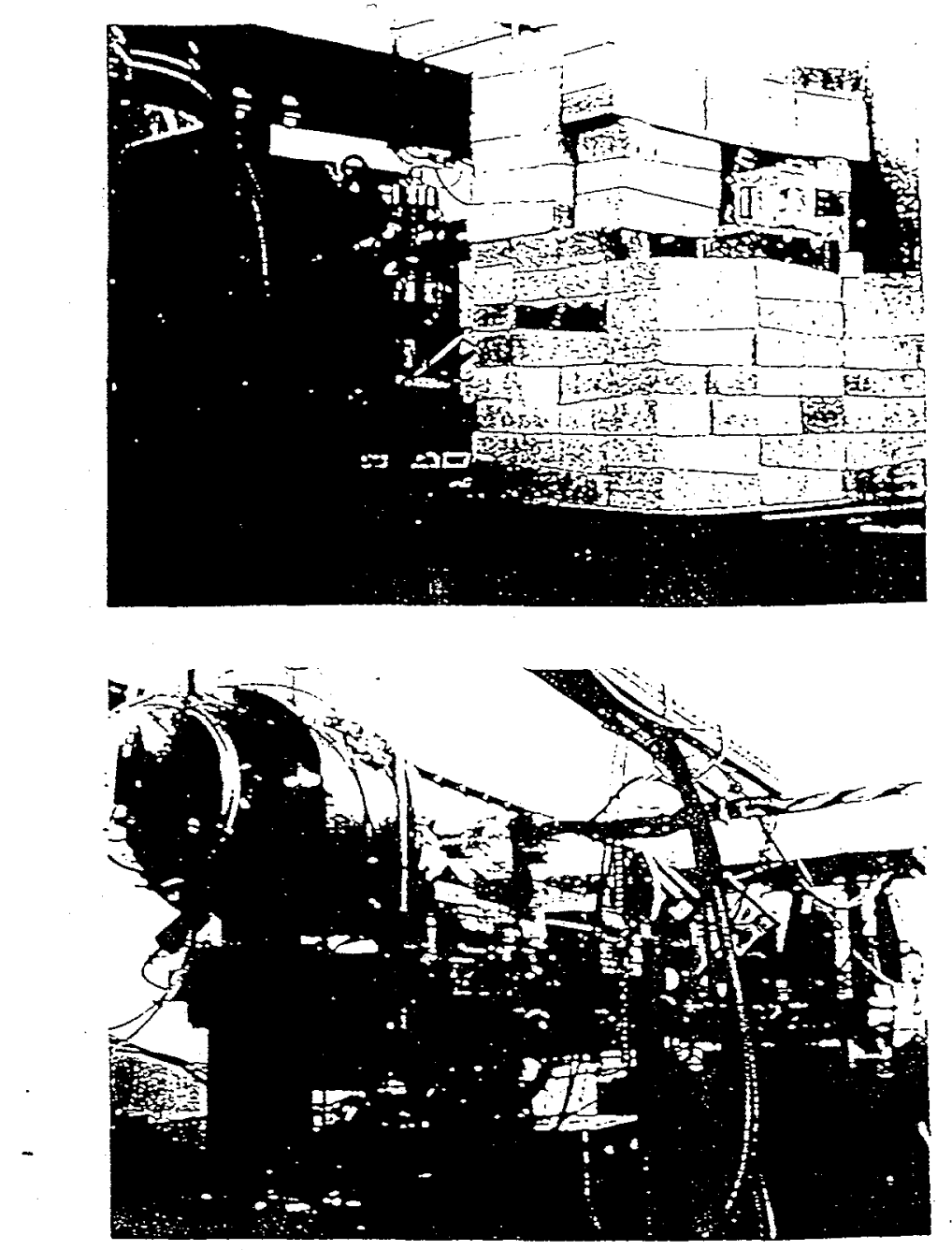

Figure 5: Photographs of the expermental humbirk set-up, with the RFQ Accelerator

\section{EXPERIMENTII METHOD}

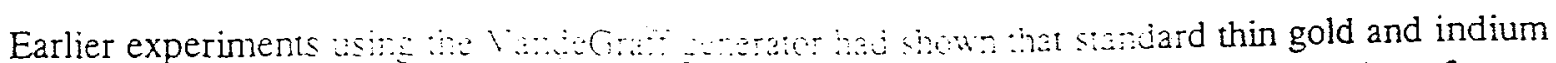

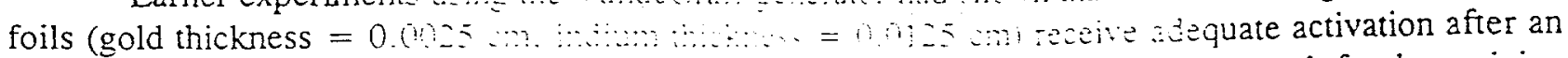
exposure of several hours. The

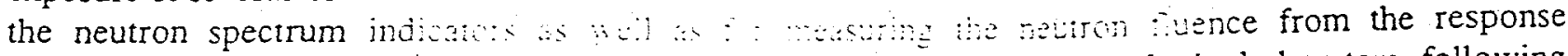

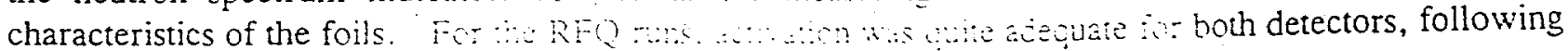

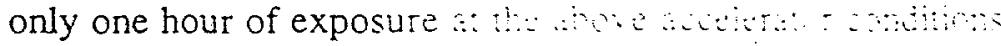

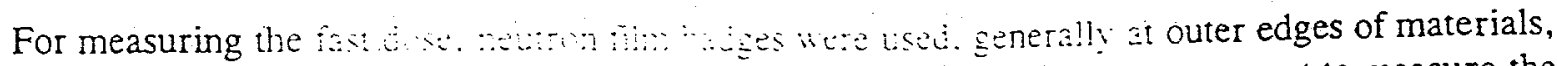

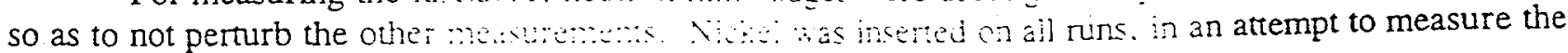

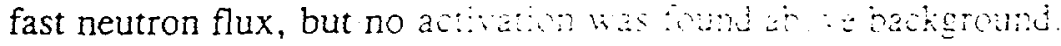

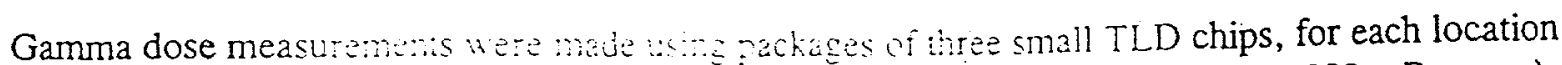
at which measurements were mid. Tha rescose an these was also adequate (50 to $1000 \mathrm{mR}$ range). Some of the film badges also renoried samma $d$ 
Two different targets were used. One was vacuum deposited natural lithium on a copper backing. The deposit of lithium was nominally 7000 Angstroms ( 0.7 microns) thick. In this quite thin layer, the proton only loses $6 \mathrm{keV}$ of energy. Thick targets (approximately $2 \mathrm{~mm}$ thick) were used on several of the runs, and this thickness was sufficient that the protons were slowed down to below the $1.88 \mathrm{MeV}$ threshold energy before leaving the lithium target material.

After each run, the target material was carefully removed, and later counted for beryllium activity. The thick target holder was built to allow for a very high water flow for target cooling, and the cooling lines came out the rear of the target. Separation of the target from the moderator by approximately 1.5 inches has a negative effect on all of the fluxes in the forward direction. However, this reduction is considered to be within the accuracy of the measurements quoted in the RESULTS section.

\section{MCNP CALCULATIONS}

The MCNP calculations were done with a recent (Dec. 1993) release of the code package for DOSbased personal computer applications, from RSIC (Oak Ridge National Lab) ${ }^{5}$. The system was modelled according to standard combinatorial geometry input, approximating as closely as possible the actual configuration. Smoothing obviously occurred on the outer dimensions of the reflector.

MCNP was run in full neutron-photon mode, so that capture gamma ray production was obtained. Consequently, photon neutron production in the heavy water was also included. and resulted in a very small fluence of high energy (well above the $0.228 \mathrm{MeV}$ maximum energy from the target) neutrons being present.

The neutron source term for the MCNP calculations was derived from the cross section data for the $\mathrm{Li}-7$ (n.p)Be-7 reaction, divided into five angular increments, with an energy spectrum developed from fractional increments of the proton beam energy between the $1.88 \mathrm{MeV}$ threshold energy and $2.0 \mathrm{MeV}$ maximum energy. The total neutron yield (for a "thick" target) was $1.97 \mathrm{E}-5$ neutrons per proton on target, nearly an order of magnitude less than the $1.48 \mathrm{E}-5 \mathrm{n} / \mathrm{p}$ yield ratio at the higher value of $2.5 \mathrm{MeV}$ used in the Ref. 1 work, as the optimum proton energy.

\section{RESULTS}

Four runs were made, two with $10 \mathrm{~cm}$ thickness of heavy water moderator, and two with $12.5 \mathrm{~cm}$ thickness. Target yields was very dependent on the centering and the focusing of the beam onto the lithium of the target. There were considerable variations in beam alignment from run to run, as could be observed by careful observation of the target appearance at the end of the run. Comparing the best yield from the thick target to the best yield from the thin target resulted in a ratio of 5 between the two. For the highest yield on the thick target, the cooling behind it was inadequate to prevent serious disintegration of the target. even to the extent of depositing lithium on the walls of the drift tube.

Because of the inconsistency in attempting to obtain uniform target performance, all the result given below are referenced to a baseline total target yield of $10^{8}$ neutrons produced by the target. Because the thick target had the further perturbation of the water lines behind the target, and the nominal $4 \mathrm{~cm}$ of separation between target and moderator, results are not quoted for those runs. The precise mochup of 
these water lines has not been done in MCNP.

The results are all quoted in rather specific units of "Total foil activations per $10^{8}$ source neutrons", and for the particular foil mass and thickness designated. The reason for such a complex indicator instead of the more conventional indicators of thermal or epithermal flux per unit target yield is the fact that the latter require very specific definition of the integral flux shape. Normal convention is to quote a MaxwellBoltzmann thermal flux and an epithermal flux, between certain energy limits, based on the criteria of a constant flux per unit lethargy. Neither of these conditions will be true for the moderator arrangements in these experiments. However, if both calculations and experiments employ the same detectors, i.e. specific foils, size, thickness, and weight, than a true comparison can be made between the calculations and experiment.

The results given in Table 1 below are for the idealized configuration shown in Figure 4, i.e. the target holder essentially in contact with the moderator.

Table 1: BENCHMARK RESULTS and COMPARISON WITH MCNP

All results are in TOTAL DETECTOR FOIL ATOMS ACTIVATED per $10^{\S}$ neutrons produced from the target.

\begin{tabular}{|l|l|l|l|l|}
\hline & \multicolumn{1}{|l|}{$10 \mathrm{~cm}$ Moderator Thickness $*$} & \multicolumn{1}{l|}{$12.5 \mathrm{~cm}$ Moderator thickness $* *$} \\
\hline & Experiment & MCNP calc. & Experiment & MCNP calc. \\
\hline Gold Foil Results, 0.001 inch thick, 0.062 grams each. 0.5 inch in diameter \\
\hline Phantom Surface & N. A. & 118 & 194 & 102 \\
\hline Phantom at depth & 215 & 112 & 135 & 52 \\
\hline Indium Foil Results. 0.005 inch thick. 0.120 grams each. 0.5 inch in diameter \\
\hline Phantom Surface & 6944 & 7146 & 5313 & 5736 \\
\hline Phantom at depth & 7524 & 8053 & 4731 & 3846 \\
\hline
\end{tabular}

The comparison between the measurements and calculations shows a tendency for the gold foil experimental results to be higher than the MCNP calculations. by the order of a factor of two. In the case of the indium foil results. the version of MCNP available ${ }^{5}$ did not contain indium activation cross section. The MCNP results were generated via a set of cross sections which the authors developed from the published cross sections in the epithermal range, and by developing these into a number of discrete energy groups. The MCNP results were then reduced into the same group structure, for generation of the foil response results quoted.

The statistical uncertainty of the MCNP results was typically 1 to 2 percent. The experimental data uncertainties were of the order of $\pm 5 \%$. except for the results at the $5 \mathrm{~cm}$ depth in the phantom. which have an uncertainty of nearer $\pm 10 \%$ 
$10 \mathrm{~cm} \mathrm{D2O,} \mathrm{3.5"} \mathrm{Phantom}$

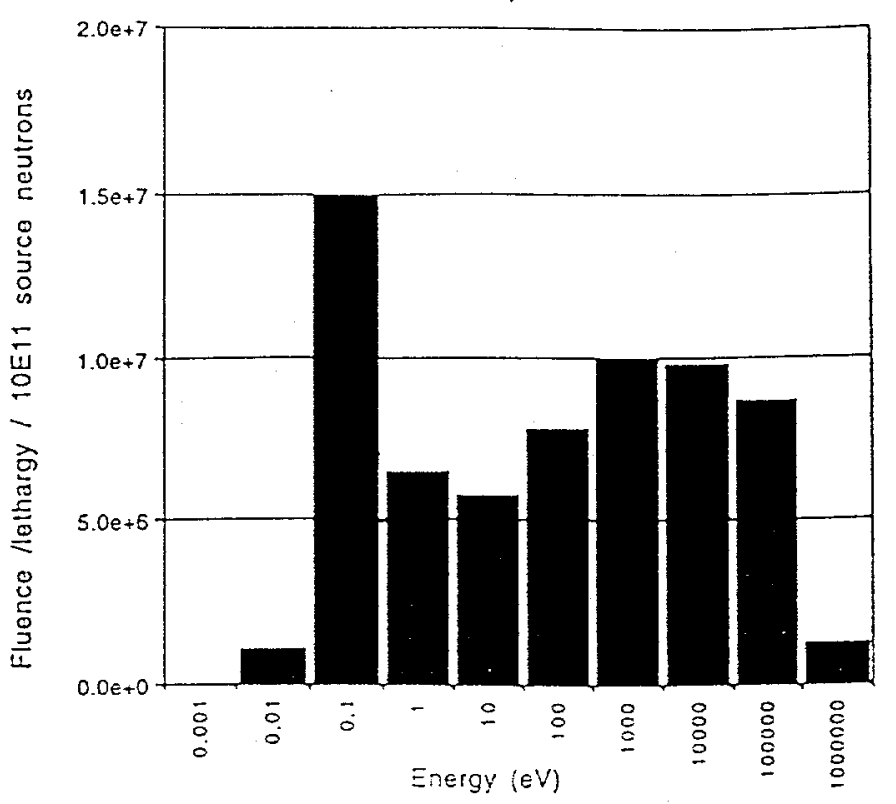

Figure 6: Neutron Fluence Spectra Histogram, Face of Phantom

Of some interest is the variation of epithermal and themal fluence across the depth of the phantom. The distribution of these two fluence types are shown in Figure 6.

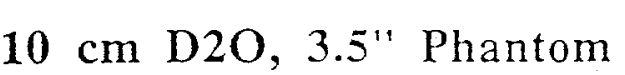
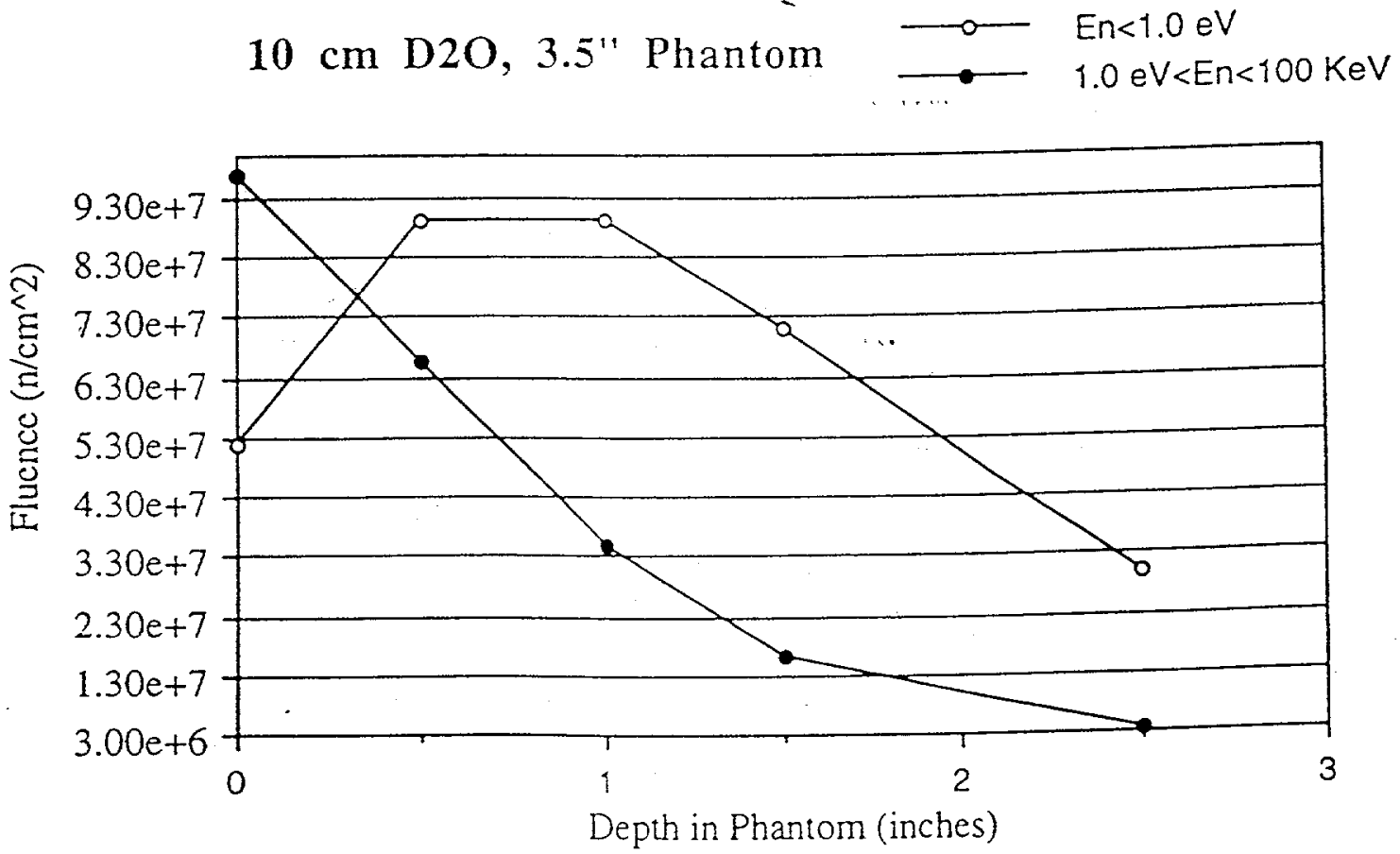

Figure 7: Fluence behavior in the phantom 
Two special situations were encountered in the experiments, which deserve mention because of the significance of these on the ultimate results.

a) The effect of the cooling water (and the aluminum casing) behind the target was considerable. MCNP runs were made with cooling water and without cooling water behind the target. The results are shown in Table 2.

b) Reflector material density would be expected to have a an effect on retention of neutrons within the system. Table 3 shows the effect between calculations with the theoretical aluminum oxide density of $3.95 \mathrm{gm} / \mathrm{cc}$ and the actual effective density in the experiment, $2.5 \mathrm{gm} / \mathrm{cc}$.

Table 2: Relative Effect of Cooling Water, $1.1 \mathrm{~cm}$ thick (and the Al wall), behind the target.

\begin{tabular}{|l|c|c|}
\hline & No Water - reference case & Water case result \\
\hline Target epithermal flux & 1.0 & 0.256 \\
\hline Phantom-face epithermal flux & 1.0 & 0.656 \\
\hline $\begin{array}{l}\text { Thermal flux 3.8 cm into } \\
\text { phantom }\end{array}$ & 1.0 & 0.785 \\
\hline \multicolumn{2}{|l|}{ Results of "water" case are relative to 1.0 for "no water" case } \\
\hline
\end{tabular}

Table 3: Relative Effect of Aluminum Oxide Reflector Density

\begin{tabular}{|l|c|c|}
\hline & $3.95 \mathrm{gm} / \mathrm{cc}$ & $2.50 \mathrm{gm} / \mathrm{cc}$ \\
\hline Target epithermal flux & 1.0 & 1.000 \\
\hline $\begin{array}{l}\text { Epithermal flux at Phantom } \\
\text { Face }\end{array}$ & 1.0 & 0.919 \\
\hline $\begin{array}{l}\text { Thermal flux at 3.8 cm depth in } \\
\text { Phantom }\end{array}$ & 1.0 & 0.832 \\
\hline Gamma Dose at Phantom Face & 1.0 & 0.720 \\
\hline
\end{tabular}

\section{CONCLUSIONS AND RECOMNENDATIONS}

As can be seen from Table 1, the MCNP results differ significantly in a few respects from the measured results. In general, the MCNP results have a statistical uncertainty in the 1 to $2 \%$ range. However, the experimental errors are much higher. Obviously, more measurements, and improved experimental results would be desirable. However, the MCNP results appear to be predicting thermal fluxes about correct at the phantom face, but MCNP appears to over-predict neutron fluxes at a depth 
of $3.8 \mathrm{~cm}$ into the phantom. The calculation appears to significantly underpredict the thermal flux at the target, but this is not a critical aspect of the design. Still, further investigation is needed to determine why this significant discrepancy between calculation and experiment.

Gamma dose rates have not been quoted, because of the wide variation in results from the duplicate detectors. Similar problems beset the attempts to determine the fast neutron dose, using neutron sensitive film. Results were inconclusive because of the high thermal neutron and gamma background.

\section{REFERENCES:}

1) Wu, H-S(Terry), R.M.Brugger and J.F. Kunze, in Advances in Neutron Capture Therapy, edited by A Solloway, R. Rolf \& D. Carpenter, p.105 to 108, (Plenum Press, 1993) proceedings of the 5th International Conference on Neutron Capture Therapy, Columbus, OH, September 1992.

2. H. Lisken and A. Paulsen, "Neutron Production Cross Sections and Energies for Reaction $\mathrm{Li}-7(\mathrm{p}, \mathrm{n}) \mathrm{Be}-7^{*}$, Atomic and Nuclear Data Tables, 15, 1,57,(1975)

3. Wang, C.K.C., T.E. Blue,\& R.Gahbauer, "A Neutronic Srudy of an Accelerator-based Neutron Irradiation Facility for Boron Neutron Capture Therapy", NUCLEAR TECHNOLOGY .84, 93 (Jan. 1989).

4. Jalondoni, D.J., Masters Degree Thesis, University of Missouri, August 1992.

5. CCC-200/MCNP 4.2 Code Package, RSIC Computer Document, Oak Ridge National Laboratory, December 1993.

ACKNOWLEDGMENTS: This work was supported under a Nuclear Engineering Education Research initiative contract from the U.S. Department of Energy, administered through the Idaho Operations Office. 